\title{
Japan-AfCFTA Integration Through Economic Impacts of Alternative EPA Scenarios
}

ONUR BIYIK ( $\sim$ biyik-onur@fuji.waseda.jp )

Waseda University

\section{Research Article}

Keywords: AfJEPA, AfJEPA-E, Welfare, Value-Added, GCE Modeling

Posted Date: July 30th, 2021

DOI: https://doi.org/10.21203/rs.3.rs-762313/v1

License: (c) (i) This work is licensed under a Creative Commons Attribution 4.0 International License. Read Full License 
Japan-Acta Integration Through Economic Impacts of Alternative EPA Scenarios ${ }^{1}$.

-Examination of the GTAP 10A MRIO Database-

\author{
Onur BIYIK \\ Graduate School of Asia-Pacific Studies, Waseca University \\ Ph.D. Candidate \\ 1-21-1 Nishiwaseda, Shinjuku, Tokyo, Japan, 165-0051 \\ biyik-onur@fuji.waseda.jp
}

${ }^{1}$ Authors wish to thank to Dr. CORONG, Erwin L and Dr. Marksym, G, for their diligent assistance and suggestions. 


\section{TABLE OF CONTENT}

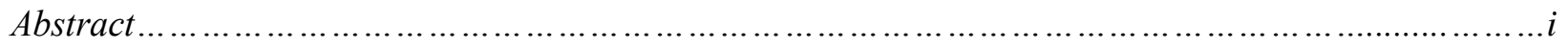

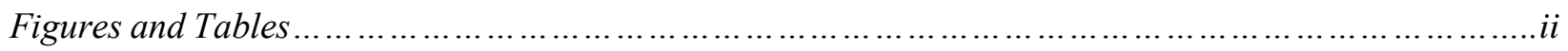

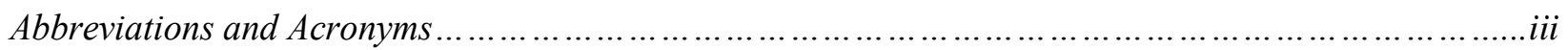

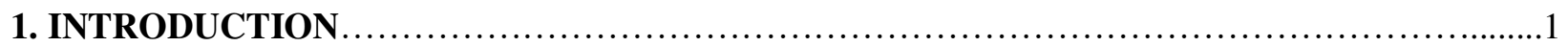

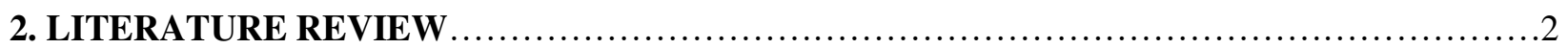

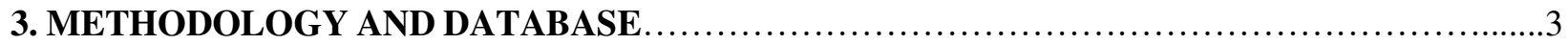

3.1.Modeling Trade Taxes and Iceberg Method...........................................4

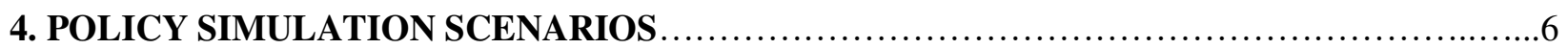

4.1. Regional and Sectoral Aggregation.............................................. 6

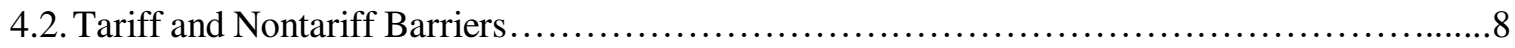

4.3. Trade Facilitation and Technological Spillover.....................................

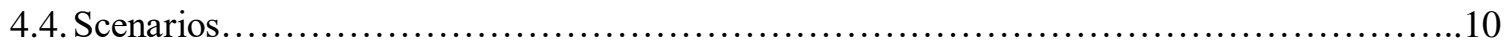

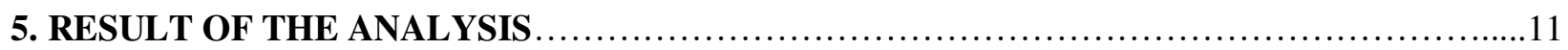

5.1. African Continental Free Trade Area-Japan Economic Partnership Agreement................12

5.2. Technological Spillover Effect in Electronic Sector, AfJEPA-E........................ 16

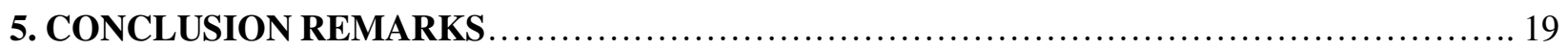

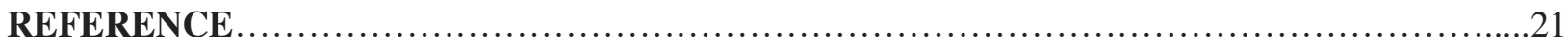

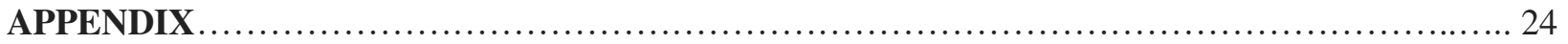

Appendix I: Modification to the Standard GTAP Model for the Long-Run Closure............... 24

Appendix II: Descriptive Statistics.............................................. 25

Appendix III: Result of MRTAs with Different Approaches..............................28 


\title{
Japan-AfCFTA Integration Through Economic Impacts of Alternative EPA Scenarios -Examination of the GTAP 10A MRIO Database-
}

\begin{abstract}
This paper analyzes the impact on an economic partnership agreement (EPA) between African countries and Japan through trade liberalization and reduction in non-tariff barriers. This study aims to investigate sectoral interconnections and participation in the EPA that would facilitate further possible opportunities for the Japan-African businesses. The methodology employed is the Computable General Equilibrium model integrated with the Global Trade Analysis Project version 10A Multi-Region Input-Output database. We first modified the GTAP's structure form to develop a long-run closure under steady-state and thereafter examined the African Continental Free Trade Area-Japan Economic Partnership Agreement (AfJEPA) with several EPAs scenarios relying on the quantitative comparison of economic impacts of different technical measurements. As a result, the AfJEPA can provide new possible opportunities for Africa-Japan businesses, such as contributing to the existing African and Japanese mega-regional trade agreements. Specifically, the electronics, petroleum and coal, and chemical, rubber, and plastic industries in Africa would see the highest percent growth. Likewise, the Japanese industries would improve their productivity in the motor vehicles and transport equipment, chemical, rubber, and plastic, and textiles and apparel industries. To sum up, trade facilitation and knowledge transfer, which policymakers can improve concrete action and investment, would considerably stimulate African and Japanese real GDP. Thus, potential for growth would rely on how deep the integration policy would be.
\end{abstract}

Keywords: AfJEPA, AfJEPA-E, Welfare, Value-Added, GCE Modeling

JEL No: C68 F13 F14 F15 F17 R13 


\section{FIGURES AND TABLES}

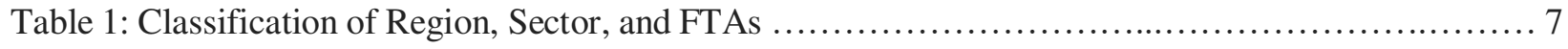

Table 2: Ad Valorem Tax Rate and Domestic Share in Total Use...................................

Table 3: Summary of Simulation Assumptions................................................. 11

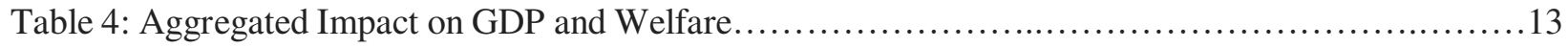

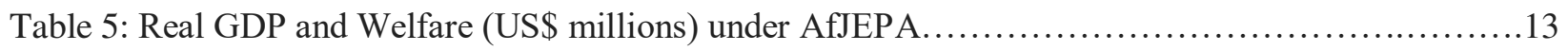

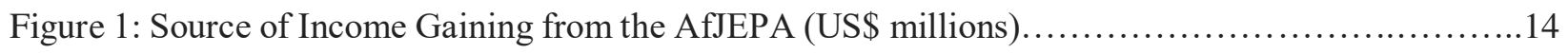

Figure 2: Value-added in Africa by the MRTAs................................................ 14

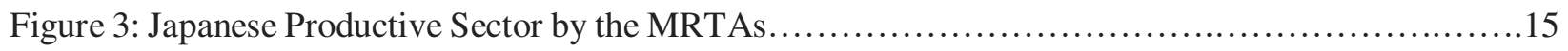

Table 6: AfJEPA-E impact in Trade Liberalization......................................... 17

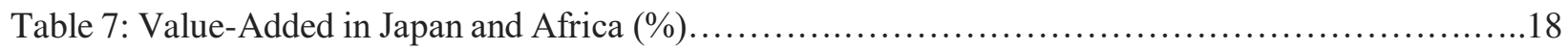

Table 8: Trade Dependence of Industrial Production and Consumption Change.........................19

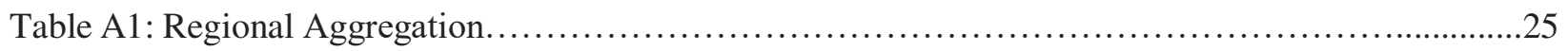

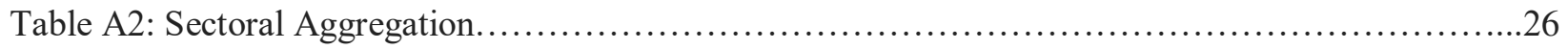

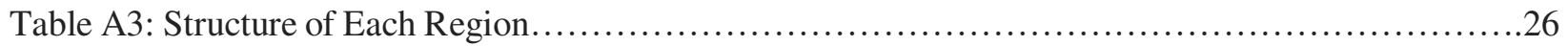

Table A4: Percent of Japanese and African Total Trade........................................27

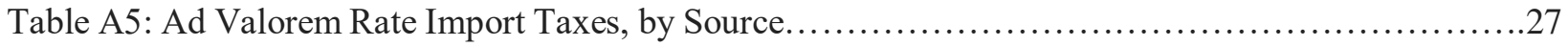

Table A6: Japan and African Integration Through Existing MRTAs...............................28

Table A7: Contribution to Each African Country's Real GDP.......................................29 


\section{ABBREVIATIONS AND ACRONYMS}

FTAs $\quad$ Free Trade Agreements

MRTAs Multi-Regional Trade Agreements

EPAs Economic Partnership Agreements

NTBs $\quad$ Non-Tariff Barriers

GTAP Global Trade Analysis Project

GCE General Equilibrium Model

MRIO Multi-Region Input-Output

RCEP Regional Comprehensive Economic Partnership

CPTPP Comprehensive and Progressive Agreement for Trans-Pacific Partnership

ASEAN Association of South-East Asian Nations

AJCEPA ASEAN-Japan Comprehensive Economic Partnership Agreement

EUJEPA European Union-Japan Economic Partnership Agreement

AfCFTA African Continental Free Trade Area

AfJEPA African Continental Free Trade Area-Japan Economic Partnership Agreement

ROW $\quad$ Rest of the World

TSE Technological Spillover Effect

SE Spillover Effect

TFA Trade Facilitation Agreement 


\section{INTRODUCTION}

The spread of Corona-19 highlights the need for international cooperation and collaboration to address global issues. There is a need to strengthen global governing bodies/mechanisms such as World Health Organization (WHO) and World Trade Organization (WTO) to function effectively. To address global issues and to maintain a coherent and peaceful society, movements such as that of the mega-regional trade agreements (MRTAs) and economic partnership agreements (EPAs) play a key process as platforms that create regional and global cooperation frameworks based on mutual trust and interest among nations with cooperative orientations. Japan and countries in Africa strive to contribute towards regional and global cooperation frameworks despite the anti-globalization and state-capitalism sentiments. Japan is not only shaping and leading the Comprehensive and Progressive Agreement for Trans-Pacific Partnership (CPTPP) but also is promoting the Regional Comprehensive Economic Partnership (RCEP). Likewise, Africa has also started increasing its free trade agreements (FTAs) and finally completed the African Continental Free Trade Area (AfCFTA) agreement. Indeed, Japan and Africa have been strengthening the links between their economies and the world economy in favor of perpetuating sustainable development and inclusive growth such as increasing each economy's welfare, and profit margin in the Global Value Chains (GVCs).

As many economies, Japanese and African industries face various problems and bottlenecks, but their participation in the EPA will facilitate further possible opportunities. Which would stimulate the development of international frameworks for promoting trade of goods and services, direct and indirect investment, and technological transfer. Also, Japan has been a bridge to strengthen the links between Africa and Asia-Pacific and acted as a front-runner in regional cooperation frameworks. Therefore, the purpose of this paper is to analyze the possible challenges and opportunities for Africa-Japan businesses. This paper examines the African Continental Free Trade Area-Japan Economic Partnership Agreement (AfJEPA) through trade liberalization and reduction in non-tariff barriers (NTBs) under the African and Japanese MRTAs. This study focuses on creative sectors and sectoral linkages, such as how much percentage of African production is necessary to meet the Japanese production and to produce African goods that are domestically consumed or exported to other countries. In conclusion, this paper makes some policy recommendations regarding the regional and sectoral integration which could boost the GDP, welfare, and other opportunities of Japan-African businesses.

Past literature reviews have focused on the impact of the CPTPP, RCEP, European Union-Japan Economic Partnership Agreement (EUJEPA), and AfCFTA (Biyik, 2020; Freund et al, 2018; Grübler et al., 2019; Ji, et al., 2018; Kawasaki, 2017; Rahman \& Ara, 2015); but to fill in the research gap and contribute to existing trade studies, this paper examined the AfJEPA by using the Computable General Equilibrium (CGE) model relying on the Global Trade Analysis Project (GTAP) version 10A Multi-Region Input-Output (GTAP- 
MRIO) database for the first time. This paper aimed to answer the following questions: to what extent of African and Japanese industries have been integrated based on production processes; how would tax policies, tariff elimination (TE), and NTBs affect each country's welfare and other macro variables; how would technological spillover and trade facilitation affect the sectors within the countries?

As a result of the AfJEPA, NTBs reduction and trade facilitation improvement compared to tariff removals would have a substantial growth in macro variables, which thereby would contribute positive value to the existing African and Japanese MRTAs. Specifically, Japanese industries would improve their productivity in the motor vehicles and transport equipment, chemical, rubber, and plastic, and textiles and apparel industries. In addition, the African electronics, petroleum and coal, and chemical, rubber, and plastic industries would see the highest percent growth. In short, this paper suggests that (i) the EPA including Japan would provide sustainable and promising growth strategies in African macro variables, (ii) trade facilitation and knowledge transfer, which policymakers can improve concrete action and investment, would considerably stimulate African real GDP, and (iii) only tariff liberalization policy would comparatively have less impact across regional real income growth. Thus, potential for growth would rely on how deep the integration policy would be.

Overall, African output relying on Japanese products is $1.4 \%$; similarly, Japanese dependence on African industrial goods is between $1.1 \%$ to $5.5 \%$ throughout East Asian countries. Therefore, the EPA would constitute a strategy for Japanese growth, which has been suffering from long-term economic stagnation, allowing Japan to integrate effects of growth outside of Asia. In addition to this, Africa would enhance its economic development strategy by learning from Japanese MRTAs' experiments and integration and would have access to the Japanese high-tech market and capital.

This paper is organized as follows: after the introduction and literature review, the third section provides an explanation of the methodology and the data. The fourth section portrays the framework of the aggregation, tariff and NTBs, trade facilitation and technological spillover, and policy scenarios. The fifth section discusses the empirical results of the AfJEPA and AfJEPA-E. The sixth section then concludes the paper.

\section{LITERATURE REVIEW}

This section reviewed recent literature about AfJEPA and considered interpreting the MRTAs, such as AfCFTA, RCEP, and CPTPP (see below, sub-section 4.1) as a base case/condition. Empirically, existing studies have already examined the regional Asia-Pacific integration and landlocked African FTA using the CGE model interacted with the GTAP database and multinational Input-Output database. 
Kawasaki (2015) and Kawasaki et al. (2019) focused on the analysis of EPAs in Asia-Pacific, such as the trans-pacific partnership (TPP) and RCEP. Other studies by Kawasaki (2017) and Ji et al. (2018) extensively examined the Asia-Pacific integration and alternative regional trade agreements (RTAs). As a result, they reported that NTBs reduction compared to tariff removals would have a strong impact on income gain, so that local market regulation would play a crucial process/role for economic growth from EPAs.

Likewise, Kuwayama (2019) examined CPTPP and alluded to the fact that building a rules-based trading system would help positively to shape the Asia-Pacific region in order to gain benefits from trade for all. Moreover, Biyik (2020), Grübler et al. (2019), and Felbermayr et, al. (2019) analyzed the EUJEPA and documented that non-tariff policy would have a positive impact on each countries' macro variables as well as supporting rules-based trading principles. Another contribution to MRTAs was when Africa finalized the AfCFTA. Accordingly, World Bank (WB) (2020a), Abrego et al. (2019), and African Development Bank (AfDB) (2020) demonstrated that the AfCFTA would have biggest benefit from reduction in NTBs and would provide many opportunity and potential gain through a degree of openness and initial level of trade barriers to each country.

Urata (2016) advocated that mega-free trade agreements (MFTAs) and the WTO could be complementary and that expanding MFTAs to a global level, will lead to the participation of new members and mergers with other MFTAs. Correspondingly, this paper also justifies that each EPA/FTA is complementary and would help to improve the agreements/relationships. In this sense, we generated our assumptions based on previous literature. Nevertheless, scholars have not comprehensively focused on the impact of the AfJEPA on contribution to MRTAs in terms of Japan and Africa. At the same time, few studies have considered the model of trade cost, the endogenous structure of capital, and exogenous trade balance. Consequently, the objective of this paper analyzed the AfJEPA and implemented the applied general equilibrium (AGE) model regarding the GTAP-MRIO database for the first time.

\section{METHODOLOGY AND DATA SOURCES}

This paper used the CGE model and GTAP-MRIO Database through which we investigated a trade integration between Japan and Africa and provided a description of (tariff) trade policy impact on each economy's future. In general, the database allows scholars to broadly evaluate the effect of a reducing tariff shock in trade studies (Hertel, 1997). Therefore, we employed the CGE model as the appropriate approach to examine the effect of AfJEPA on Japanese and African markets. This paper modified closure under 
alternative long-run closure rules, such as capital accumulation and (perfect) capital mobility ${ }^{2}$ following Walmslye (1998) and Francois et al., (1996), as seen in Appendix I.

As for the limited African countries' international trade integrated database ${ }^{3}$, the GTAP database is to provide the most available data for African countries. The GTAP-MRIO database, which was launched in 2020 (Carrico, et al., 2020) and accounts for 65 sectors in each of the 141 regions, relies on the linkage model by implementing the GTAP 10A with the 2014 base year. The GTAP-MRIO model extends the standard GTAP, such as introducing agent (end-user as firms, consumers, and investors), and provides time series of input-output tables, bilateral trade flows, transport costs, tax (income and factor) and tariff information, and all other data calculating based on Social Accounting Matrices and elasticity parameters (Aguiar et al., 2019; Carrico et al., 2020; Hertel, 1997). The GTAP Database has denominated in millions of base year (2014) US dollars.

\subsection{Modeling Trade Taxes and Iceberg Method}

In the GCE model, we implemented tax policies and illustrated a simulation of the trade liberalization and reduction in NTBs. This paper draws tax and iceberg-related equations, following Walmsley Strutt (2019) and Kawasaki (2015). As for the demand function, demand for import $\left(Q_{s, d}\right)$ relies on Armington CES in the GTAP model obtained from maximizing utility function ${ }^{4}\left(U_{s, d}=\left[\sum_{s=1}^{n}\left(Q_{s \cdot d}\right)^{\rho}\right]^{-\frac{1}{\rho}}\right)$ and budget constrain $\left(X_{d}=\left[\sum_{s=1}^{n} P_{s, d} \cdot Q_{s, d}\right]\right)$. Policymakers use the import and export taxes $T\left(1+T_{s, d}^{m}\right.$, representing the GTAP model) to estimate trade liberalization. Thus, import demand with trade taxes represents in Armington (1969):

$$
Q_{s, d}=Q_{d}\left[\frac{P_{s, d}\left(1+T_{s, d}^{m}\right)}{P_{d}}\right]^{\sigma}
$$

$P_{s, d}$ is the prices of import $\mathrm{c}$ from $\mathrm{s}$ for use by region $\mathrm{d}$, inclusive of import tax price.

Where: $\mathrm{c}$ is the community, $\mathrm{s}$ is the source country, and $\mathrm{d}$ is the destination country.

Equation 1 is formalized in the GTAP-MRIO model:

$$
Q X S_{c, s, d}=Q I M_{c, d}\left[\frac{P C I F_{c, s, d} \cdot T M S_{c, s, d}}{P M S_{c, d}}\right]^{-E S U B M_{c}}
$$

\footnotetext{
${ }^{2}$ Although some study suggested for saving to be invested in the home country, this paper assume perfect capital mobility becau se foreign capital contributing high growth rate in host country.

${ }^{3}$ Possible MRIO datasets: the WIOD, Exipol, EORA, and GTAP which Owen (2017) and Walmsley at al. (2014) provide more detailed

${ }^{4} \rho$ is an elasticity of substitution parameter between goods in different countries which account for $\left(\sigma=\frac{1}{1+\rho}\right)$.
} 
Equation (2) shows that when tariff, $T M S A_{c, a, s, d}\left(T M S_{c, s, d}\right)$, start imposing or eliminating, import price change depends on the import of $\mathrm{c}$ from s (exporter) for use by agent (a) in region d (importer).

$P_{d}$ (or $P M S_{c, d}$ in the GTAP-MRIO) is the commodity price of import in region d;

$\sigma$ (or $E S U B M_{c}$ in GTAP-MRIO) is the elasticity of substitution between goods from different countries s;

$Q_{s, d}$ (or $Q X S_{c, s, d}$ in GTAP-MRIO) is the demand for goods from the county s by country d; and

$Q_{d}\left(\right.$ or $Q I M_{c, d}$ in GTAP-MRIO) is the demand for imported goods by d.

In the concept of import and export linkages, the free on board (FOB) price and the cost, insurance, and freight (CIF) prices link for export and import prices for each commodity.

In percent changes as a shown lowercase letter in the GTAP-MRIO model:

$$
\begin{gathered}
p a m d s_{c, a, s, d}=p c i f_{c, s, d}+t m s_{C, s, d} \\
p f o b_{c, s, d}=p d s_{C, s, d}+t x s_{c, s, d}
\end{gathered}
$$

Where: pamds $_{c, a a . s . d}$ is the basic price of import c from s for use by an agent a in $\mathrm{d}$;

$p f o b_{c, s, d}$ is the FOB price of commodity c from source s to destination d;

pcif $f_{c, s, d}$ is the PCIF price of commodity c from source s to destination d;

$p d s_{c, s, d}$ is the price of commodity c from source s;

$t m s_{c, s, d}$ is the import tax rate applied on commodity c; and

$t x s_{c, s, d}$ is the export tax rate applied c.

Tariff elimination leads to a reduction of the cost of input and subsequently has a positive impact on the flow of commercial products. Also, trade facilitation agreements and NTBs improving the quality of commercial goods maximize the FTAs' potential benefits. Accordingly, it is the most common approach to model the trade facilitation in trade liberalization and NTBs, we use the iceberg cost variable, $\tau_{s, d}$ or $A M S_{c, s, d}$ which presents "value melt away". Therefore, the demand for import $\left(\frac{Q_{s, d}}{\tau_{s, d}}\right)$ changes so that utility function becomes; $U_{s, d}=\left[\sum_{s=1}^{n}\left(\frac{Q_{s, d}}{\tau_{s, d}}\right)^{\rho}\right]^{-\frac{1}{\rho}}$ and budget constraint becomes; $X_{d}=\left(\sum_{s=1}^{n} P_{s, d} \cdot \frac{Q_{s, d}}{\tau_{s, d}}\right)$. Demean function would be formalized in equation 5: 


$$
\frac{Q_{s, d}}{\tau_{s, d}}=Q_{d} \cdot\left[\frac{P_{s, d} \cdot \tau_{s, d}}{P_{d}}\right]^{\sigma}
$$

$P_{s, d}$ is the prices of import $\mathrm{c}$ from $\mathrm{s}$ for use by region $\mathrm{d}$, inclusive of iceberg cost.

In the GTAP model,

$$
\frac{Q X S_{s, d}}{A M S_{c, s, d}}=Q I M_{c, d}\left[\frac{P C I F_{c, s, d} \cdot A M S_{c, s, d}}{P M S_{c, d}}\right]^{-E S U B M_{c}}
$$

In percent changes as a shown lowercase letter in the GTAP-MRIO model:

$$
q x s_{c, s, d}=q m s_{c, d}-a m s_{c, s, d}-E S U B M_{c}\left(p a m d s_{c, a, s, d}-a m s_{c, s, d}-p m s_{c, d}\right)
$$

Where: $a m s_{c, s, d}$ is the percent change in augmenting iceberg cost of commodity c from s to d; and

$q m s_{c, d}$ is the percent change of aggregate imports of commodity c in each region.

Hertel et al. (2001) and Walmsley and Strutt (2019) expressed that the iceberg cost variable $\left(\tau_{s, d}\right.$ or $A M S_{c, s, d}$ ), which substitutes quantity demand by reducing the input price of an imported commodity through Armington CES, reduces the amount of imported goods because of the productivity effect from technological change. These two opposite directions have a positive impact on reducing the price and increasing demand due to the different multiplier elasticity on domestic and import goods. Nevertheless, note that $a m s_{c, s, d}$ shock ${ }^{5}$ directly creates productivity shock and thereby boosts real GDP growth considerably (Walmsley \& Strutt, 2019).

\section{POLICY SIMULATION SCENARIOS}

Scholars extensively use the GTAP model to document economic integration and FTAs, applying reductions in trade costs, liberalization of agriculture and industry, and the cross-border flow of people, capital, and technology (Hertel, 2013; van Meijl \& van Tongeren, 1999). In this section, we summarized the information on the implication of regional and sectoral aggregation and tariff liberalization and reduction in NTBs, as well as trade facilitation and technological spillover impact on FTAs.

\subsection{Regional and Sectoral Aggregation}

Firstly, Japan has a high FTAs coverage ratio of export and import, more than 80\% (Table A4). ASEANJapan Comprehensive Economic Partnership Agreement (AJCEPA) took effect in 2008. In terms of mega FTAs, CPTPP and EUJEPA were a force in 2018, and 2019, respectively. Lastly, after the Indian decision

${ }^{5}$ However, Walmsley and Strutt, (2019) investigated that using the AMS shock is inconsistent with the impact on importing countries in terms of real trade volume that quantity exported is less that quantity imported. 
of RCEP, it finally signed in November 2020. Likewise, African countries (44 of its 55 member states) signed the AfCFTA agreement in March 2018 and came into force in April 2019 for 22 countries (African Union, 2019).

As for regional and sectoral aggregation, we aggregated the data depending on Japanese and African FTAs and past literature contributions. Thus, this study used the 2014-year base as the last reference year and aggregated 12 regions and 18 sectors (Table 1), as shown in the GTAP concordance in Appendix II. Specifically, we first eliminetd tariff levels of the AfCFTA and the Japanese MRTAs to be a baseline condition and right after started examining the AfJEPA. Which would present potential gain from each agreement and would demonstrate the contribution of the new EPA to Japan and Africa.

Table 1: Classification of Region, Sector, and FTAs

\begin{tabular}{|c|c|c|c|}
\hline Regions & Origin of Classification Name & Sectors & Origin of Classification Name \\
\hline Japan & Japan (JPN) & Agriculture & Agriculture (AGR) \\
\hline Korea & Republic of Korea (KOR) & Fossilfuels & Fossil fuels (FFL) \\
\hline China & China (CHN) & Minerals & Minerals, NES (OXT) \\
\hline USA & The United States of America (USA) & ProcFood & Processed foods (PFD) \\
\hline India & India (IND) & WoodPro & Wood and paper products (WPP) \\
\hline ANZ & Australia (AUS), New Zealand (NZL) & TextWapp & Textiles and wearing apparel (TWP) \\
\hline ASEAN6 & $\begin{array}{l}\text { Cambodia (KHM), Indonesia (IDN), Lao PDR (LAO), } \\
\text { Philippines (PHL), Thailand (THA), rest of Southeast } \\
\text { Asia-Myanmar-(XSE) }\end{array}$ & EnergyIPro & Energy-intensive manufacturing (KE5) \\
\hline ASEAN4 & $\begin{array}{l}\text { Malaysia (MYS), Singapore (SGP), Brunei Darussalam } \\
\text { (BRN), Vietnam (VNM) }\end{array}$ & PetCoal & Petroleum and coal products (P_C) \\
\hline CMCP & Canada (CAN), Mexico (MEX), Chile (CHL), Peru (PER) & CheRuPla & Chemical, rubber, and plastic products (CRP) \\
\hline$E U$ & The European Union (EU)'s 27 countries & Manufactures & Manufactures, NES (XMN) \\
\hline Africa & AfCFTA countries & Electronic & Electronics (XELE) \\
\hline \multirow[t]{2}{*}{ ROW } & Rest of the World & Automobile & Motor vehicles and transport equipment. (MVT) \\
\hline & & Construct & Construction (CNS) \\
\hline AJCEPA & Japan, ASEAN4, ASEAN6 & TradeServic & Trade services (TRD) \\
\hline CPTPP & Japan, ASEAN4, CMCP, ANZ & TransComm & Transport and Communication Service (TPCS) \\
\hline RCEP & Japan, Korea, China, ASEAN4, ASEAN6, ANZ & FinanServ & Financial services, NEC (OFI) \\
\hline EUJEPA & Japan, EU & BusiServ & Business services (XBS) \\
\hline AfJEPA & Japan, Africa & PublicServ & Public services (XSV) \\
\hline
\end{tabular}

On one hand, each country regarding FTA has a different economic structure following the percentage of expenditure in GDP and population in the world. For example, the export percent in ASEAN countries' GDP is comparatively much higher than the export percent in East Asian countries' GDP. Moreover, while EUJEPA, RCEP, and CPTPP have positive trade balance, AfJEPA's export is lower than its import (Table A3). Furthermore, RCEP, AfCFTA, EUJEPA, and CPTPP account for 30.3\%, 17\%, 7.9\%, and 6.8\% world population, respectively (Table A3). Therefore, enhancing each economic integration, such as AfJEPA, would provide a possible opportunity for the world population. 


\subsection{Tariff and Nontariff Barriers}

Regarding GTAP data version 10A, the reference year 2014, tariff data shows import tax imposed in RCEP countries have higher tariff levels than CPTPP members due to the heavily protected processed food industries (Table A5). Likewise, the African import tariff level is higher than the Japanese. In addition to inter-sector tariff heterogeneity, Africa protects its manufacturing industries in which average tariffs are close to $8 \%$. Conversely, Japanese tariffs on the manufacturing industries are around 0 while Japanese tariffs on agriculture, processed food, and textile industries are comparatively higher than other industries in Japan (Table 2). Regarding sectoral self-sufficiency which presents a domestic share in total use, the Japanese market heavily depends on the import of energy resources and agriculture goods while electronic and automobile industries are highly self-efficient to export. As for the African economy, it is a rich energy resource landlocked but needs to meet mainly foreign manufacturers to produce its own goods. Thus, Japanese industries import energy resources from Africa whose industries import more motor vehicles and transport equipment from Japan (Table 2).

Table 2: Ad Valorem Tax Rate and Domestic Share in Total Use

\begin{tabular}{|c|c|c|c|c|c|c|}
\hline & \multicolumn{4}{|c|}{ Bilateral Trade Flow of Japan and Africa } & \multicolumn{2}{|c|}{$\begin{array}{c}\text { Sectoral Self- } \\
\text { Sufficiency }\end{array}$} \\
\hline & \multicolumn{2}{|c|}{ Japanese Export to Africa } & \multicolumn{2}{|c|}{ African export to Japan } & \multirow{2}{*}{ Japan } & \multirow{2}{*}{ Africa } \\
\hline & Tariff $(\%)$ & Value (\$) & Tariff $(\%)$ & Value (\$) & & \\
\hline Agriculture & 3.9 & $\$ 7$ & 2.1 & $\$ 697$ & 0.765 & 0.995 \\
\hline Fossilfuels & 0.1 & $\$ 0$ & 0 & $\$ 9,003$ & 0.010 & 3.380 \\
\hline Minerals & 0.4 & $\$ 2$ & 0 & $\$ 1,210$ & 0.215 & 1.690 \\
\hline ProcFood & 4.7 & $\$ 79$ & 6.3 & $\$ 538$ & 0.850 & 0.885 \\
\hline WoodPro & 6.9 & $\$ 25$ & 0.1 & $\$ 227$ & 0.909 & 0.819 \\
\hline TextWapp & 7.1 & $\$ 273$ & 7.3 & $\$ 159$ & 0.463 & 0.765 \\
\hline EnergyIPro & 6 & $\$ 1,045$ & 0.2 & $\$ 3,452$ & 1.060 & 1.060 \\
\hline PetCoal & 6.3 & $\$ 235$ & 0.7 & $\$ 954$ & 0.927 & 0.663 \\
\hline CheRuPla & 8.3 & $\$ 1,018$ & 0.1 & $\$ 255$ & 1.090 & 0.661 \\
\hline Manufactures & 7.4 & $\$ 271$ & 0.2 & $\$ 31$ & 0.971 & 0.709 \\
\hline Electronic & 6 & $\$ 953$ & 0 & $\$ 32$ & 1.130 & 0.473 \\
\hline Automobile & 13.3 & $\$ 9,340$ & 0 & $\$ 723$ & 1.430 & 0.496 \\
\hline Construct & 0 & $\$ 1,275$ & 0 & $\$ 180$ & 1.000 & 0.978 \\
\hline TradeServic & 0 & $\$ 540$ & 0 & $\$ 429$ & 1.000 & 0.995 \\
\hline TransComm & 0 & $\$ 488$ & 0 & $\$ 1,426$ & 1.030 & 1.060 \\
\hline FinanServ & 0 & $\$ 71$ & 0 & $\$ 64$ & 0.983 & 0.982 \\
\hline BusiServ & 0 & $\$ 1,015$ & 0 & $\$ 714$ & 0.976 & 0.888 \\
\hline PublicServ & 0 & $\$ 391$ & 0 & $\$ 407$ & 0.996 & 0.991 \\
\hline
\end{tabular}

Source: GTAP 10A, author's calculations.

Moreover, trade services function to set up businesses, such as banks, to strengthens the connection between countries which leads to a smooth flow of commercial products. On the other hand, trade-in service is difficult to capture an impact by tariff but is instead affected by behind-the-border regulations and technical measurements such as Technical Barrier to Trade (TBT) and Sanitary and Phytosanitary (SPS) standard, as 
known NTBs simulating growing concern healthy and quantity and environmental attributes (Herghelegiu, 2018). Accordingly, many studies documented that reduction in NTBs is more beneficial to stimulate trade than the only tariff policy (Kee, et al., 2009; Webb et al., 2020).

Implementing NTBs in GTAP, this paper first translated NTBs to ad valorem equivalents (AVE) to be incorporated into the tariff and export taxes by applying the Altertax procedure (Malcolm, 1998), which modified the original database to minimize disturbances. In other words, this paper designed the model to minimize the changes to the rest of the database while the required change in tax rates is large (Walmsley \& Strutt, 2019). The NTB changes were assumed to imply to most-favored-nation (MFN) countries. Moreover, it was assumed that removing tariffs in the NTBs would have 50\% with spillover effect (SE) to third countries at $50 \%$. In other words, GDP gain from NTBs reduction relies on assuming a $50 \%$ of NTBs reduction with a 50\% spillover effect. If the AVEs of NTBs in the RCEP member of Japan is 10\%, we have assumed Japan will reduce the AVEs of NTBs by 5\% (50\% of NTBs) for the imports from RCEP member countries and by $2.5 \%$ (50\% spillover effects of 50\% NTBs reductions) from non-RCEP member countries. This is due to the reduction of the cost of compliance with foreign standards and regulations. This assumption was based on previous studies on AfCFTA, RCEP, and CPTPP (Kawasaki, 2017; Maliszewska \& Ruta, 2020; Petri \& Plummer, 2016). Estimating the quantification of NTBs from the Word Integrated Trade Solution (WITS) relies on Kee, Nicita, and Olarreaga's (2009) study. Moreover, service sectors in NTBs are documented by Jafari and Tarr (2017). This special case used trade weighs regarding the model's regions and sectors aggregated.

\subsection{Trade Facilitation and Technological Spillover}

Trade facilitation interacts with the cost of time delay at the border. Such FTA/EPA partners aim to improve reciprocal trade facilitation provisions that would lead to the smooth flow of commercial goods. For instance, CPTPP and ASEAN documented the "custom procedures under the trade in goods", representing advance ruling such as defining a harmonized standard, tariff classification, and valuation criteria and rules of origin are to secure participants and customers, as well as Niamey Declaration in AfCFTA (Ji et al., 2018; WB, 2020). Empirically, ADB and UNESCAP (2013) represented that the trade facilitation measurement had a positive impact on enhancing export/import performance and trade competitiveness, FDI, and GDP. Accordingly, this paper assumes that implementing the WTO's Trade Facilitation Agreement (TFA) ${ }^{6}$ under

EPAs/FTAs would have the benefit of average trade cost reduction of $0.9 \%$ for imports and $1.2 \%$ for export

\footnotetext{
${ }^{6}$ Scholars commonly use the iceberg cost variable ( $\tau_{s, d}$ or $\left.a m s_{c, s, d}\right)$ to model trade facilitation.
} 
relying on Hillberry and Zhang (2018) study, roughly $7 \%$ for AfCFTA regarding Maliszewska et al. (2020) and Melo and Sorgho (2019) papers.

In addition, joining the GVCs through FTA, which accounts for strong firm-to-firm relationships and specialization (specializing in specific parts and components) for the long term (WB, 2020b), can boost growth, create more jobs, and importantly reduce poverty (Aldaba, 2012; Nabeshima, et al., 2018). For example, empirical studies documented that international trade stimulated the cross-border flow of technology because knowledge is embodied in goods (Coe, Helpman, \& Hoffmaister, 1997) so that a country importing commodities and receiving FDI is directly influenced by technology depending on its absorption capacity and its structural similarity (van Meijl et al, 1998). WB (2020b) also reported that multinational firms relocating their productions such as designing, producing, and assembling parts and components due to the most cost-effective location would have to exchange knowledge when their products meet the border restrictions, such as import-related law and regulations. Accordingly, such an emerging imitation or innovation in a country allows firms to reduce their input cost that may trigger an increase in their output under the multi-region and general equilibrium setting. This represents technical change gaining a competitive edge over exporters on the world market. Thus, this paper assumed that the cross-border flow of the knowledge would have the benefit of reducing an average of between $0.1 \%$ and $0.5 \%$ of input cost in trade commodities (Table 3). Basically, we assumed that the degree of knowledge regarding the percentage of export and import in total bilateral trade (Table A4) were to transfer: (i) from Japan to Africa and from Africa to Japan (whole sectors) (ii) only from Japan to Africa (electronic sector in particular). Note that the technological spillover effect (TSE) relies on strong assumptions through a technical change in the GTAP model. We implemented a simple assumption is to fit the closure. Further, we also address this limitation in sub-section 5.2, below.

\subsection{Scenarios}

In the policy experiment, this paper used the full version of model structure and parameter values regarding the aggregated data to represent economic reality in trade liberalization function as accurately as possible. This paper also examined selected FTAs/EPAs by estimating the quantification of the NTBs (Table 3). To capture the reality of the selected FTAs, this paper's assumptions were in line with previous studies on CPTPP, RCEP, and AfCFTA (Ji et al., 2018; Kawasaki, 2017; Maliszewska \& Ruta, 2020; Petri \& Plummer, 2016). In literature, common sense is that policymakers should consider underpinning trade facilitation, NTBs, and connectivity measurements that demonstrate a potential fruit of FTAs. To evaluate the quantitative impacts of selected FTAs, this paper implemented series of trade-related shocks: (1) up to full tariff elimination; (2) $50 \%$ of reduction in NTBs with $50 \%$ of a spillover effect to third countries; (3) up to 
$2.1 \%$ (roughly $7 \%$ for AfCFTA) of reduction of time in customs due to the TFA and up to $0.5 \%$ of the cross-border flow of technological spillover effect (Table 3).

Table 3: Summary of Simulation Assumptions

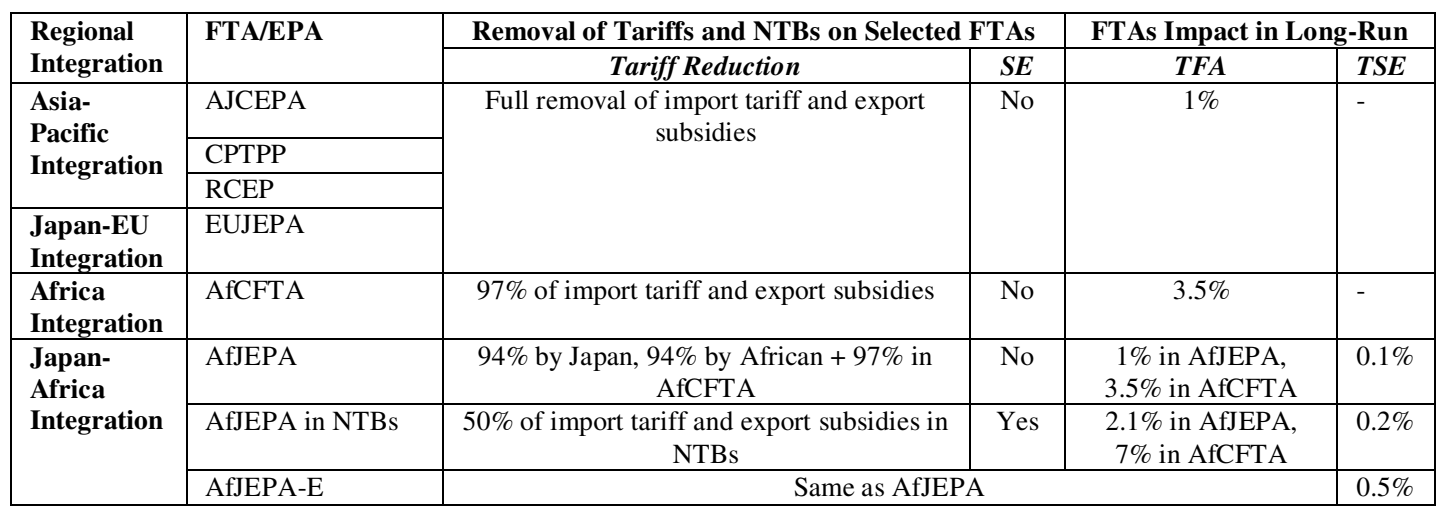

Note: SE: Spillover Effect; TFA: Trade Facilitation Agreement; TSE: Technological Spillover Effect.

Source: Author's assumptions.

\section{RESULTS OF THE ANALYSIS}

This section presents the result of this paper's questions. We first modified the GTAP's structure form to develop a long-run closure (long-term macroenvironment) under steady-state, as shown in Appendix I. The long-term macroenvironment, through which capital can be mobile across regions, causes capital shock depending on a rate of return across regions and across time. We comparatively examined the two different approaches, $E X P A N D^{7}$ and $R O R C^{8}$, impact on real GDP growth and welfare ${ }^{9}$, which will be discussed results in subsection 5.2, below. The difference is that in the case of 'expand' closure, 'rorc' remains endogenous, but is equalized across regions, while a change in investment relative to endowment stock is fixed/exogenous. When 'rorc' became closure works, such as everything is captured by the expansion/change in quantities. Moreover, 'rorc' has a positive correlation with a rental price of capital through substitution between capital and labor. Two different compensatory effects cause the price of capital goods to change: The first effect is a decrease in the price of capital goods due to the reduction in tariffs on imported inputs into capital goods and the second effect is conversely an increase of the price of capital goods because of increased demand for inputs (Walmsley, 1998)

As for portraying the result, this paper, firstly, eliminated tariffs for the AfCFTA and the Japanese MRTAs which created the base data set so that this paper would present the contribution of AfJEPA to Japan and Africa. Secondly, this paper displayed the AfJEPA, through which this paper revealed the trade facilitation

\footnotetext{
${ }^{7}$ expand(e,r) = qinv(r) - qe(e,r) in GTAP-MRIO; " $r$ " is region and "e" is capital

${ }^{8} \operatorname{rorc}(\mathrm{r})=$ GRNETRATIO(r) * $[\operatorname{rental}(\mathrm{r})-\operatorname{pinv}(\mathrm{r})]$ in GTAP-MRIO; the rental price is determined by capital goods.

${ }^{9}$ See more detail in Francois et al. (1996) Walmsley (1998) papers.
} 
improvement (TFI), NTBs, and TSE. Lastly, the knowledge transfer occurs in mainly electronics-related technology which was implemented and indicated the final scenario (AfJEPA-E) impact on each industrial value-added (Table 3). This section was divided into two subsections, sub-suction 5.1 and 5.2 below, and implemented long-run closure for the scenarios. We did not focus on presenting results with baselines simulation because the AfJEPA is a possible EPA. In other words, we did not consider updated data to run baseline scenarios due to minimizing unnecessary distortion. Nevertheless, we considered the contribution of economic impacts of several EPA scenarios relying on the quantitative comparison of economic impacts of different technical measurements, such as rorc and expand. Therefore, this paper's result came out differently than previous studies. Also, we preferred to demonstrate the equivalent variation (EV) and the real GDP impacts which look more familiar to policymakers.

\subsection{African Continental Free Trade Area-Japan Economic Partnership Agreement}

This paper analyzed the AfJEPA because of a sectoral integration, as presented in Appendix III. A sectoral integration between Japan and Africa, the AfCFTA would contribute by 0.004 percent of Japanese GDP, and the Japanese MRTAs would stimulate African GDP to increase between $0.001 \%$ to $0.015 \%$ throughout East Asian countries (Table A6). To enhance this integration, this paper suggested the EPA between Japan and Africa, called AfJEPA. In other words, not only would the AfJEPA constitute a strategy for growth for Japan suffering from long-term economic stagnation and allow Japan to integrate the effect of growth outside of Asia, but also Africa would enhance its economic development strategy by learning from Japanese MRTAs' experiment and would have accessed the Japanese high-tech market and capital.

Primarily, reducing tariff level leads comparatively to cheaper input, which constitutes competitiveness of local goods. Therefore, the AfJEPA would subsidize the African and Japanese markets and benefits to member countries, lowering the price of import and benefits customers of final (household) and intermediate (firms) goods. Therefore, trade liberalization and reduction in NTBs would deliver more promising gains for member countries. However, while there are countries with a higher level of MFN border protection and trade-to-GDP ratio that would gain more, imposing a low level of prevailing MFN tariff rates countries would have modest benefit through the EPA (Table 4 and Table A6)

In general, we analyzed the AfJEPA by implementing the two different approaches of 'rorc' and 'expand' closure. Technically, 'rorc' closure has a strong impact on real GDP than 'expand' closure; in contrast, the impact of 'rorc' closure on welfare gain compared to 'expand' closure has significantly less effect (Table 4). This is because 'expand' closure leads (regional) saving to be invested in the home country and thereby is likely to improve (national) household income. In other words, 'rorc' closure with endogenous 'expand' allows the capital shock to spread out across regions and thereafter has a positive impact on other nations' 
welfare and GDP due to the positive effect of the flow of commercial goods. For instance, the EU with 'rorc' closure which is not the trade deal would have a positive impact on its welfare from the AfJEPA due to EUJEPA and regional integration with Africa (Table 4). In short, while the 'rorc' swap leads to comparatively higher impacts on GDP growth due to the large increase in capital shock, 'expand' swap has a strong effect on raise welfare due to the regional saving and investment correlation. Therefore, to capture the efficient impact of the AfJEPA on macro variables, this paper preferred to present the result of the macro variables by using 'rorc' swap, but only welfare by implementing 'expand' swap because each variable should take into account different approaches regarding their own different condition.

Table 4: Aggregated Impact on Real GDP and Welfare

\begin{tabular}{|c|c|c|c|c|c|c|c|c|c|}
\hline & \multicolumn{3}{|c|}{ NTBs } & \multicolumn{3}{|c|}{ Trade Liberalization } & \multicolumn{3}{|c|}{ Welfare (US\$ millions) } \\
\hline & \multirow{2}{*}{ Standard } & \multicolumn{2}{|c|}{ Long-Run Closure } & \multirow[t]{2}{*}{ Standard } & \multicolumn{2}{|c|}{ Long-Run Closure } & \multirow{2}{*}{ Standard } & \multicolumn{2}{|c|}{ Long-Run Closure } \\
\hline & & EXPAND & $R O R C$ & & EXPAND & RORC & & EXPAND & $R O R C$ \\
\hline Africa & 0.378 & 1.366 & 1.147 & 0.198 & 0.619 & 0.834 & $\$ 7,399$ & $\$ 16,338$ & $\$ 12,479$ \\
\hline Korea & 0.011 & 0.097 & 0.11 & -0.003 & 0.017 & 0.018 & $(\$ 261)$ & $(\$ 106)$ & $\$ 232$ \\
\hline USA & 0.001 & 0.005 & 0.008 & 0 & 0.006 & 0 & $(\$ 505)$ & $\$ 214$ & $\$ 112$ \\
\hline India & 0.015 & 0.127 & 0.069 & -0.005 & 0.007 & 0 & $(\$ 497)$ & $(\$ 385)$ & $\$ 124$ \\
\hline EU & 0.009 & 0.071 & 0.046 & -0.004 & 0.025 & 0.027 & $(\$ 2,074)$ & $\$ 1,255$ & $\$ 2,892$ \\
\hline
\end{tabular}

Note: Standard references to standard GTAP model (RORDELTA=1)

Source: GTAP 10A MRIO Data Base, author's estimation

As a result of empirical analysis, AfJEPA would boost Japanese GDP by $0.175 \%$ in tariff elimination (TE) and $0.319 \%$ in NTBs, and African GDP by $0.834 \%$ in TE and $1.147 \%$ in NTBs (Table 4). This agreement with capital mobility would also stimulate other regions' GDP. For example, the EU could have a positive impact and could increase its GDP by $0.027 \%$ in TE and $0.046 \%$ in NTBs with capital shock; however, the AfJEPA would harm non-members' GDP in TE in terms of implementing standard closure, without capital shock (Table 4).

Table 5: Real GDP and Welfare (US\$ millions) under AfJEPA

\begin{tabular}{|c|c|c|c|c|c|c|c|c|c|}
\hline & \multicolumn{3}{|c|}{ NTBs with $R O R C$} & \multicolumn{3}{|c|}{ Trade Liberalization with $R O R C$} & \multicolumn{3}{|c|}{ Welfare (EV) with $E X P A N D$} \\
\hline & $\begin{array}{c}\text { Tariffs } \\
\text { only }\end{array}$ & $\begin{array}{c}\text { Tariffs and } \\
\text { TFA/TFI }\end{array}$ & $\begin{array}{c}\text { Tariffs and } \\
\text { TSE } \\
\end{array}$ & $\begin{array}{c}\text { Tariffs } \\
\text { only }\end{array}$ & $\begin{array}{c}\text { Tariffs and } \\
\text { TFA }\end{array}$ & $\begin{array}{c}\text { Tariffs and } \\
\text { TSE } \\
\end{array}$ & $\begin{array}{c}\text { Tariffs } \\
\text { only }\end{array}$ & $\begin{array}{c}\text { Tariffs and } \\
\text { TFA } \\
\end{array}$ & $\begin{array}{c}\text { Tariffs and } \\
\text { TSE }\end{array}$ \\
\hline Japan & 0.031 & 0.064 & 0.286 & 0.015 & 0.032 & 0.158 & $\$ 943$ & $\$ 1,272$ & $\$ 3,774$ \\
\hline Africa & 0.253 & 0.939 & 0.461 & 0.295 & 0.733 & 0.397 & $\$ 763$ & $\$ 6,259$ & $\$ 1,903$ \\
\hline Korea & 0.088 & 0.098 & 0.1 & 0.006 & 0.012 & 0.012 & $(\$ 136)$ & $(\$ 248)$ & $(\$ 149)$ \\
\hline China & 0.074 & 0.082 & 0.083 & 0.002 & 0.005 & 0.007 & $(\$ 782)$ & $(\$ 1,400)$ & $(\$ 912)$ \\
\hline USA & 0.005 & 0.006 & 0.006 & -0.001 & -0.003 & -0.001 & $(\$ 238)$ & $(\$ 412)$ & $(\$ 331)$ \\
\hline India & 0.025 & 0.036 & 0.035 & -0.002 & -0.004 & 0 & $(\$ 235)$ & $(\$ 473)$ & $(\$ 259)$ \\
\hline EU & 0.008 & 0.009 & 0.009 & 0.01 & 0.021 & 0.016 & $(\$ 971)$ & $(\$ 1,933)$ & $(\$ 1,112)$ \\
\hline
\end{tabular}


This paper also investigated each instrument variable's impact, such as a calibrated change by only tariff effect, tariff and trade facilitation agreement (TFA), and tariff and technological spillover effect (TSE), respectively. Accordingly, we can track the most stimulant variable regarding GDP and welfare. It is also obvious that Japanese and African economic structures are different from their firms' input cost of land and labor. For example, while the TSE has a comparatively higher impact on Japanese real GDP than trade facilitation improvement (TFI), Africa gaining benefit from TFI would have remarkably a crucial effect of welfare than TSE (Table 5).

Figure 1: Source of Income Gaining from the AfJEPA (US\$ millions)

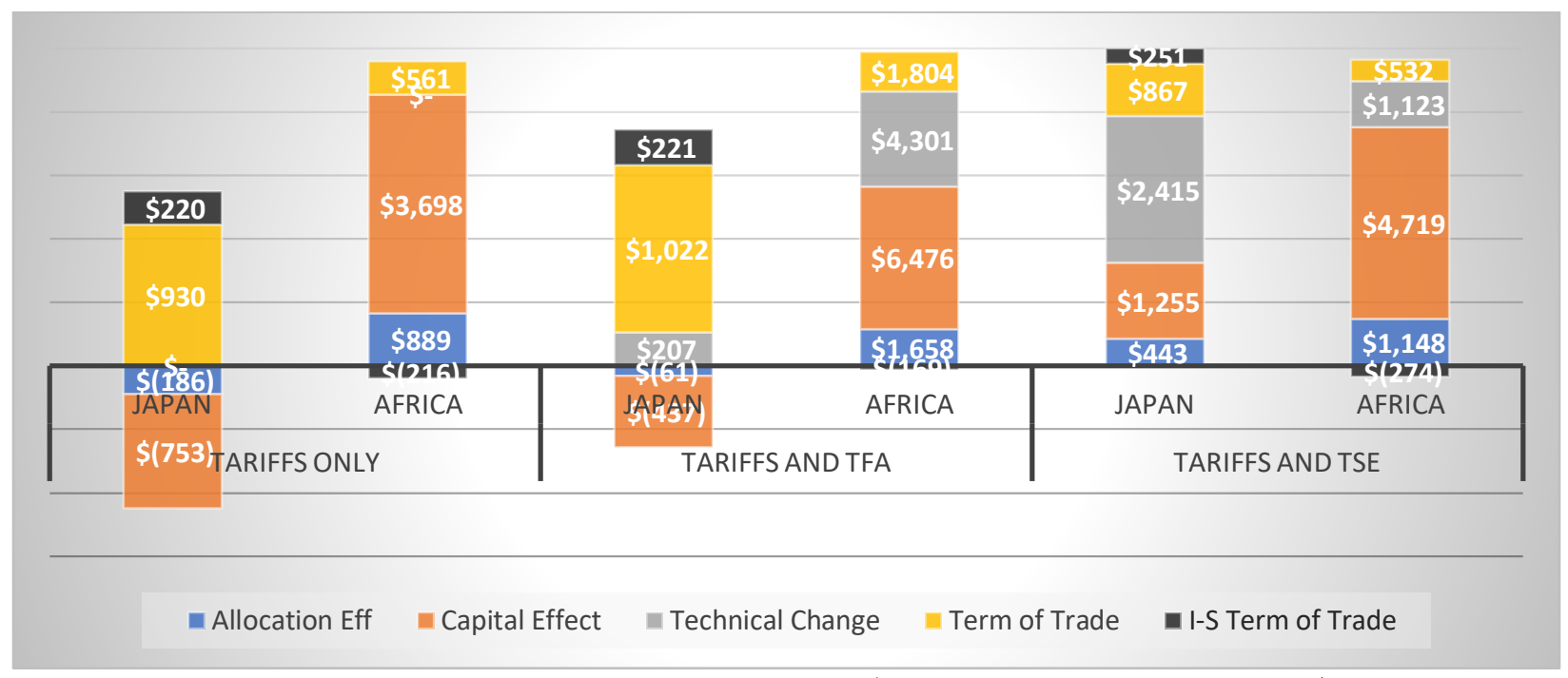

Note: TFA: Trade Facilitation Agreement; TSE: Technological Spillover Effect. \$() represents minus/negative value of US\$ millions

Source: GTAP 10A MRIO Data Base, author's estimation

\section{Figure 2: Value-added in Africa by the MRTAs}

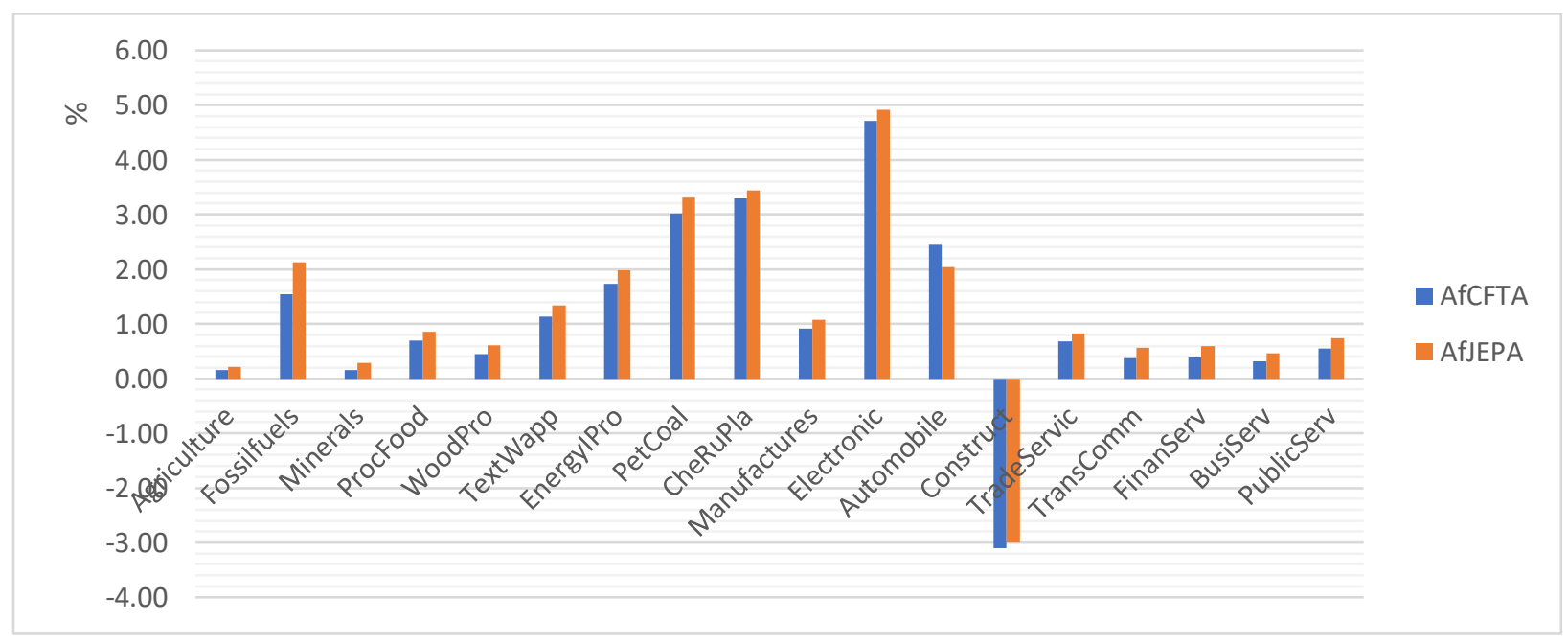

Source: GTAP 10A MRIO Data Base, author's estimation 
To recapitulate the finding of the different instrument experiments, TFI and TSE have a larger impact on GDP than only tariff elimination. This is due to the fact that technological change directly increases the amount of production, but tariff elimination relatively affects saving and allocative effect, and mainly the term of trade effect in Japan and capital effect in Africa (Figure 1). Empirically, while the African market is quite sensitive to the TFI impact, boosting GDP by $0.733 \%$ in TE and $0.939 \%$ in NTB, the Japanese economy influences larger effect from TSE, enhancing GDP by $0.158 \%$ in TE and 0.286 in NTBs (Table 5), as well as the same impact accrued on their welfare growth (Figure 1). Africa would get a higher total welfare change due to the contribution of capital and allocation effect is positive, but negative in Japan which would cause by factor movement into the distorted each sector. Furthermore, another effect of the AfJEPA would have a negative value in African saving in which the TSE variable would lead to shrinking comparatively more (Figure 1).

\section{Figure 3: Japanese Productive Sector by the MRTAs}

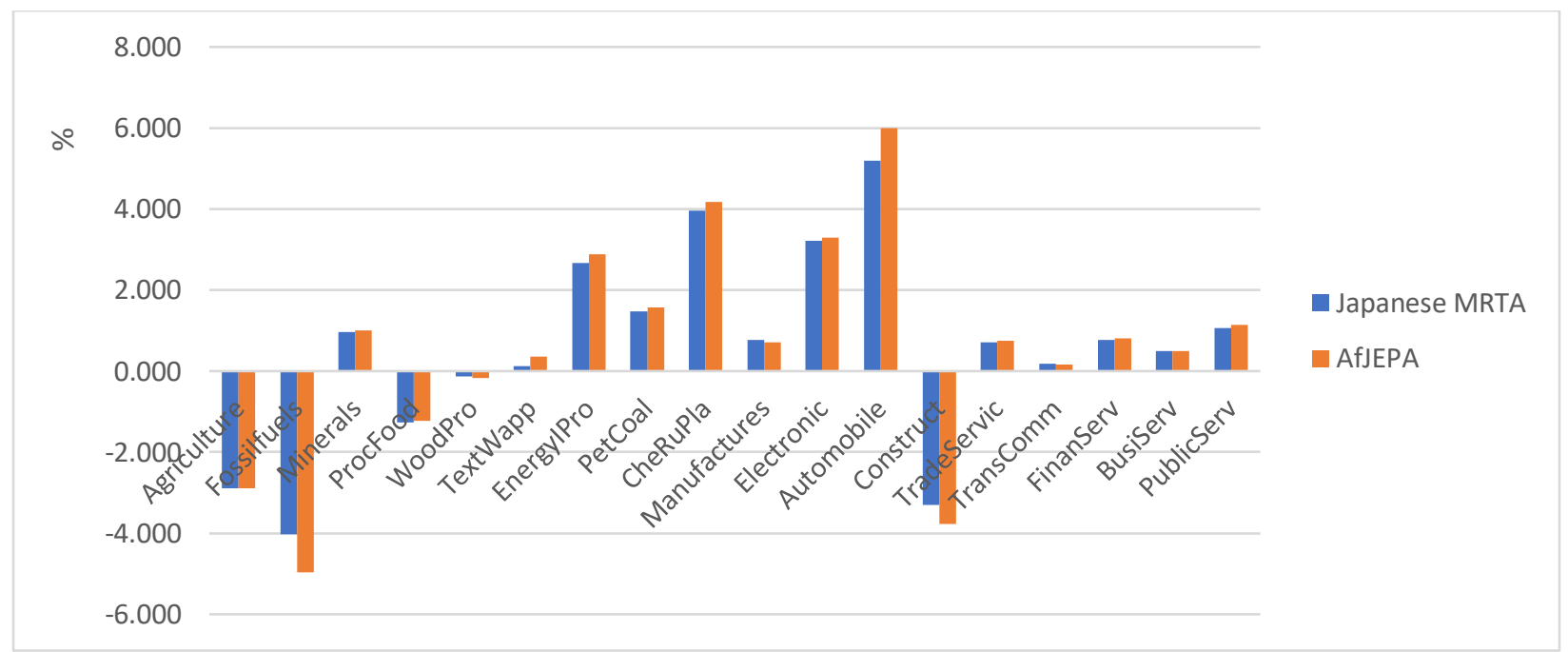

Source: GTAP 10A MRIO Data Base, author's estimation

In this subsection, we demonstrated each agreement's contribution to African value-added and Japan's output percent change. Value-added would increase higher because capital, allocative, and technological improvements positively impact on factors (Figure1) that move out of the subsidized sectors (Figure 2). The AfJEPA would indeed contribute to AfCFTA and thereby have a positive impact on African valueadded, the highest growth in the fossil fuel industry particularly (Figure 2). Likewise, adding a new EPA to Japanese MRTAs would comparatively have a small impact on Japanese output due to the regional and sectoral integration through export/import percent (Table A4) and therefore could contribute a positive impact on the output of agriculture, processed foods, wood and paper, manufacturing, and service industries mainly (Figure 3). 
To summarize the key points here, we documented that GDP is not a useful instrument to present national welfare $^{10}$ (Table 4). We also reported that tariffs and TFA have a substantial impact on the Japanese and African economies. However, firms' cost of input relying on TSE analysis would be biased to distribute the possible impact on selected countries because this change should consider a specific technical change in the GTAP model, such as Meijl et al., (1999) did. Therefore, we modified the final scenario of AfJEPA-E to be a proper/simple approach and investigates it in subsection 5.2, below.

\subsection{Technological Spillover Effect in Electronic Sector, AfJEPA-E}

This subsection provided information on the final scenario that accounts for the different technological spillover effects from Japan to Africa (Table 3). An empirical study documented that most of the knowledge accrues in mainly consumer electronics industries, such as television, computer, and phone (van Meijl et al., 1999). Also, Timmer (1988) and van Meijl et al., (1999) analytically portrayed the "biased technical change in the agricultural sector" due to the limited experiment capacity of biological and mechanical technology. Moreover, Japan has relatively a higher land and labor share in its costs and, therefore, would receive a larger gain than Africa through TSE (Table 5 and Figure 1). In that sense, we assumed there would be a $0.5 \%$ technological spillover effect on only African electronic sectors from the advanced/innovative country, Japan (Table 3). Since we investigated different impacts of each instrument (Tariff and TFA) on real GDP and welfare in the subsection of 5.1, above, we focused on presenting the AfJEPA-E effect on African and Japanese macroeconomic variables in this subsection.

Table 6 shows the real GDP growth and welfare change for only Japan and African countries. The AfJEPA would provide many opportunities for Japan-African business, as well as non-members countries (Table 5; 6). African countries would enjoy through not only AfCFTA but also AfJEPA-E (Table 6; Table A7). Specifically, Southern Africa would have a relatively higher real income growth rate and welfare gain (by $1.49 \%$ and 6,496 US\$ millions, respectively) than other regions. As for each country ${ }^{11}$, Namibia, Botswana, and Burkina Faso could be the top three highest real GDP growth rate countries, increasing ${ }^{12}$ by $10.14 \%$, $4.94 \%$, and $4.04 \%$, respectively. Besides, East and North Africa would importantly improve their welfare gain. Similarly, the Japanese economy gaining benefits from AfJFTA-E would improve its real income by 0.03\%. More importantly, including Japan in the EPA compared to AfCFTA would remarkably hike up real GDP in Egypt and Tunisia, increasing from $0.07 \%$ to $0.30 \%$ and from $0.17 \%$ to $0.43 \%$, respectively

\footnotetext{
${ }^{10}$ Walmsley (1998) also reported that GDP change by ownership of capital shock does not consider and should not be correlated welfare change. However, dynamic model can capture the change in the ownership of capital and rental income earned which represents impact of regional income on regional welfare.

${ }^{11}$ As for AfJEPA-E contribution to each African country, we presented comparatively AfCFTA and AfJEPA-E in Appendix III (Table A7).

${ }^{12}$ Note that the large difference in distribution between Japan and African countries' GDP is because of the distribution of trade-related shocks, export/import percent in total trade, and regional integration.
} 
(Table A7). In addition to this, TSE-related electronics would have a relatively strong impact on Tunisia and the Rest of South Africa (Table A7).

Table 6: AfJEPA-E Impact in Trade Liberalization

\begin{tabular}{|c|c|c|c|c|c|c|c|c|}
\hline & \multicolumn{4}{|c|}{ Real GDP with $R O R C$} & \multicolumn{4}{|c|}{ Welfare (EV) with EXPAND } \\
\hline & Total & $\begin{array}{c}\text { Tariffs } \\
\text { only }\end{array}$ & $\begin{array}{c}\text { Tariffs and } \\
\text { TFA }\end{array}$ & $\begin{array}{c}\text { Tariffs and } \\
\text { TSE } \\
\end{array}$ & Total & $\begin{array}{c}\text { Tariffs } \\
\text { only }\end{array}$ & $\begin{array}{c}\text { Tariffs and } \\
\text { TFA }\end{array}$ & $\begin{array}{c}\text { Tariff and } \\
\text { TSE }\end{array}$ \\
\hline Japan & 0.033 & 0.015 & 0.032 & 0.015 & $\$ 982$ & $\$ 232$ & $\$ 960$ & $\$ 255$ \\
\hline Africa & 0.776 & 0.295 & 0.732 & 0.339 & $\$ 14,798$ & $\$ 5,216$ & $\$ 14,019$ & $\$ 5,996$ \\
\hline Northern Africa & 0.341 & 0.132 & 0.289 & 0.184 & $\$ 2,220$ & $\$ 850$ & $\$ 1,923$ & $\$ 1,146$ \\
\hline Egypt & 0.302 & 0.179 & 0.261 & 0.221 & $\$ 332$ & $\$ 322$ & $\$ 248$ & $\$ 406$ \\
\hline Morocco & 0.273 & 0.061 & 0.23 & 0.104 & $\$ 489$ & $\$ 199$ & $\$ 447$ & $\$ 242$ \\
\hline Central African & 1.24 & 0.608 & 1.21 & 0.638 & $\$ 1,372$ & $\$ 782$ & $\$ 1,348$ & $\$ 806$ \\
\hline Cameroon & 0.603 & 0.398 & 0.59 & 0.411 & $\$ 130$ & $\$ 65$ & $\$ 126$ & $\$ 69$ \\
\hline Southern Africa & 1.497 & 0.549 & 1.419 & 0.627 & $\$ 6,398$ & $\$ 2,048$ & $\$ 6,064$ & $\$ 2,382$ \\
\hline Namibia & 10.139 & 2.692 & 10.042 & 2.79 & $\$ 870$ & $\$ 296$ & $\$ 862$ & $\$ 304$ \\
\hline Botswana & 4.938 & 0.602 & 4.91 & 0.63 & $\$ 476$ & $\$ 27$ & $\$ 474$ & $\$ 30$ \\
\hline East African & 1.022 & 0.37 & 0.992 & 0.4 & $\$ 3,383$ & $\$ 1,314$ & $\$ 3,292$ & $\$ 1,405$ \\
\hline Ethiopia & 0.314 & 0.241 & 0.303 & 0.251 & $\$ 173$ & $\$ 109$ & $\$ 168$ & $\$ 115$ \\
\hline Kenya & 0.769 & 0.353 & 0.715 & 0.407 & $\$ 394$ & $\$ 154$ & $\$ 366$ & $\$ 182$ \\
\hline Mozambique & 3.118 & 0.754 & 3.095 & 0.777 & $\$ 438$ & $\$ 91$ & $\$ 435$ & $\$ 94$ \\
\hline Western Africa & 0.72 & 0.353 & 0.692 & 0.381 & $\$ 1,773$ & $\$ 757$ & $\$ 1,695$ & $\$ 834$ \\
\hline Burkina Faso & 4.044 & 2.242 & 3.999 & 2.287 & $\$ 437$ & $\$ 235$ & $\$ 432$ & $\$ 240$ \\
\hline Senegal & 1.817 & 0.689 & 1.738 & 0.768 & $\$ 412$ & $\$ 160$ & $\$ 403$ & $\$ 169$ \\
\hline
\end{tabular}

Note: TFA: Trade Facilitation Agreement; TSE: Technological Spillover Effect.

Source: GTAP 10A MRIO Data Base, author's estimation

This paper also supports Strutt's and Walmsley's (2019) paper and documented that the iceberg cost variable $\left(\tau_{s, d}\right.$ or $\left.a m s_{c, s, d}\right)$ has a productivity impact through reducing the cost of (importer) rent which leads to directly boost value-added growth. The larger you use TFA/TSE the larger productivity is to boost directly sectoral output and value-added. Also, the African tariff rate is higher than the Japanese tariff level (Table 2). As a result, African industries would have a positive impact from the tariff, tariff plus TFA, tariff plus TSE, and thereupon could considerably improve their value-added. In detail, the electronics, petroleum and coal and chemical, rubber, and plastic industries in Africa would be the highest percent growth while only the African construction industry would have a negative value, shrinking by $3.17 \%$ (Table 7 ). Besides, the Japanese industries would improve their productivity in the motor vehicles and transport equipment, chemical, rubber, and plastic, and textiles and apparel industries; however, the fossil fuel and construction industries in Japan would negatively have an influence on value-added (Table 7).

Table 8 shows the result of industrial production and consumption change through AfJEPA-E. That is, we investigated the trade dependence of industrial production and consumption change because of a traderelated policy strategy for policymakers. As a result of the EPA, the Japanese and African industrial export share in total production would increase due to the decreased trade-related input cost and increased trade 
flow of commercial goods. Specifically, whereas the Japanese mining, fossil fuel, and financial service industries' export percent in total output could shrink, the automobile, construction, and textile and apparel industries in Japan would take leads, increasing by $0.9 \% 0.5 \%$, and $0.4 \%$, respectively (Table 8 ). However, Japanese import share in its industrial consumption has a different structure. The consequences of increased export would forward the energy-intensive manufacturing and automobile industries in Japan to demand more for import products due to the limited Japanese energy resource; however, the Japanese construction, manufacture, and electronics industries would comparatively decrease to consume import-related production (Table 8 ).

Table 7: Value-Added in Japan and Africa (\%)

\begin{tabular}{|c|c|c|c|c|c|c|c|c|}
\hline \multirow[b]{2}{*}{ Sectors } & \multicolumn{4}{|c|}{ Africa } & \multicolumn{4}{|c|}{ Japan } \\
\hline & $\begin{array}{c}\text { Only } \\
\text { Tariffs }\end{array}$ & $\begin{array}{c}\text { Tariffs } \\
\text { and TFA }\end{array}$ & $\begin{array}{c}\text { Tariffs } \\
\text { and TSE }\end{array}$ & Total & $\begin{array}{c}\text { Only } \\
\text { Tariffs } \\
\end{array}$ & $\begin{array}{c}\text { Tariffs } \\
\text { and TFA }\end{array}$ & $\begin{array}{c}\text { Tariff } \\
\text { and TSE }\end{array}$ & Total \\
\hline Agriculture & 0.087 & 0.196 & 0.096 & 0.205 & -0.012 & -0.022 & -0.011 & -0.021 \\
\hline Fossilfuels & 0.832 & 2.065 & 0.967 & 2.2 & -0.167 & -1.021 & -0.185 & -1.038 \\
\hline Minerals & 0.257 & 0.259 & 0.26 & 0.262 & 0.071 & 0.021 & 0.069 & 0.019 \\
\hline ProcFood & 0.403 & 0.789 & 0.424 & 0.811 & -0.002 & 0.007 & -0.001 & 0.007 \\
\hline WoodPro & 0.394 & 0.55 & 0.39 & 0.545 & -0.037 & -0.039 & -0.037 & -0.039 \\
\hline TextWapp & 0.635 & 1.228 & 0.665 & 1.257 & 0.137 & 0.166 & 0.137 & 0.166 \\
\hline EnergyIPro & 0.888 & 1.868 & 0.911 & 1.891 & 0.174 & 0.158 & 0.172 & 0.156 \\
\hline PetCoal & 1.525 & 3.195 & 1.58 & 3.251 & 0.04 & 0.062 & 0.039 & 0.062 \\
\hline CheRuPla & 1.57 & 3.304 & 1.613 & 3.347 & 0.139 & 0.16 & 0.139 & 0.159 \\
\hline Manufactures & 0.671 & 0.97 & 0.677 & 0.975 & -0.087 & -0.076 & -0.086 & -0.075 \\
\hline Electronic & 2.807 & 4.732 & 3.426 & 5.35 & -0.001 & 0.004 & -0.008 & -0.004 \\
\hline Automobile & 1.097 & 1.884 & 1.161 & 1.947 & 0.659 & 0.734 & 0.659 & 0.734 \\
\hline Construct & -0.962 & -3.029 & -1.1 & -3.168 & -0.439 & -0.461 & -0.435 & -0.457 \\
\hline TradeServic & 0.407 & 0.777 & 0.449 & 0.819 & -0.009 & 0.002 & -0.009 & 0.002 \\
\hline TransComm & 0.256 & 0.513 & 0.289 & 0.546 & -0.053 & -0.046 & -0.052 & -0.045 \\
\hline FinanServ & 0.245 & 0.53 & 0.279 & 0.564 & 0.005 & 0.017 & 0.006 & 0.017 \\
\hline BusiServ & 0.205 & 0.423 & 0.238 & 0.456 & -0.02 & -0.01 & -0.02 & -0.01 \\
\hline PublicServ & 0.245 & 0.656 & 0.284 & 0.695 & 0.026 & 0.043 & 0.027 & 0.043 \\
\hline
\end{tabular}

Source: GTAP 10A MRIO Data Base, author's estimation

The African manufacturing industries' export share in total production would marginally rise, such as automobile and electronic sectors could shoot up by $14.8 \%$ and $13.3 \%$, respectively, whereas servicesbased sectors would decrease their export percent in total production. The consequences of increased export would trigger the fossil fuel, processed food, and textile and apparel industries to demand more importrelated goods, increasing by $12,23 \%, 2.07 \%$, and $1.22 \%$, respectively (Table 8 ). In contrast, the construction and electronics industries in Africa would reduce consumption of the import goods. In short, the result is to also show a promising signal that Africa would improve the production of the manufacturing-related sectors in total export such as an Asian development relied on export oriented and impoprt substitution growth strategy, increasing export-related manufacturing goods; however, the African service sector has a 
negative impact from the EPA so that policymakers should consider more TFI and regional regulation policy (Table 8), such as infrastructure investments.

Table 8: Trade Dependence of Industrial Production and Consumption Change

\begin{tabular}{|c|c|c|c|c|c|c|c|c|c|c|c|c|}
\hline & \multicolumn{6}{|c|}{ Export Share of Industrial Production a } & \multicolumn{6}{|c|}{ Import Share of Industrial Consumption ${ }^{b}$} \\
\hline & \multicolumn{3}{|c|}{ Africa } & \multicolumn{3}{|c|}{ Japan } & \multicolumn{3}{|c|}{ Africa } & \multicolumn{3}{|c|}{ Japan } \\
\hline & $\begin{array}{l}\text { Tariffs } \\
\text { only }\end{array}$ & $\begin{array}{c}\text { Tariff } \\
\text { and } T F A\end{array}$ & $\begin{array}{l}\text { Tariff } \\
\text { and TSE }\end{array}$ & $\begin{array}{l}\text { Tariffs } \\
\text { only }\end{array}$ & $\begin{array}{l}\text { Tariff } \\
\text { and TFA }\end{array}$ & $\begin{array}{l}\text { Tariff } \\
\text { and TSE }\end{array}$ & $\begin{array}{l}\text { Tariffs } \\
\text { only }\end{array}$ & $\begin{array}{l}\text { Tariff } \\
\text { and TFA }\end{array}$ & $\begin{array}{l}\text { Tariff } \\
\text { and TSE }\end{array}$ & $\begin{array}{l}\text { Tariffs } \\
\text { only }\end{array}$ & $\begin{array}{l}\text { Tariff } \\
\text { and TFA }\end{array}$ & $\begin{array}{l}\text { Tariff } \\
\text { and TSE }\end{array}$ \\
\hline Agriculture & 0.354 & 1.086 & 0.292 & 0.165 & 0.241 & 0.173 & 1.46 & 2.84 & 1.489 & 0.004 & 0.02 & 0.003 \\
\hline Fossilfuels & -0.03 & 1.033 & -0.007 & -0.287 & -0.294 & -0.316 & 1.709 & 12.232 & 1.694 & 0.001 & -0.17 & -0.002 \\
\hline Minerals & 0.008 & 0.206 & 0.013 & -0.088 & -0.071 & -0.087 & 0.201 & -1.385 & 0.14 & 0.051 & -0.176 & 0.048 \\
\hline ProcFood & 5.458 & 9.776 & 5.441 & 0.108 & 0.1 & 0.107 & 1.316 & 2.07 & 1.319 & 0.055 & 0.067 & 0.054 \\
\hline WoodPro & 5.26 & 11.486 & 5.279 & 0.114 & 0.09 & 0.113 & 0.904 & 1.08 & 0.866 & -0.176 & -0.167 & -0.174 \\
\hline TextWapp & 2.962 & 5.383 & 2.954 & 0.377 & 0.434 & 0.377 & 0.757 & 1.221 & 0.752 & 0.022 & 0.023 & 0.022 \\
\hline EnergyIPro & 1.501 & 3.629 & 1.538 & 0.147 & 0.203 & 0.144 & 0.653 & 0.191 & 0.594 & 0.169 & 0.353 & 0.171 \\
\hline PetCoal & 6.118 & 10.276 & 6.141 & 0.154 & 0.238 & 0.152 & 0.585 & -0.004 & 0.562 & 0.027 & -0.008 & 0.027 \\
\hline CheRuPla & 5.125 & 10.875 & 5.125 & 0.098 & 0.101 & 0.097 & 0.914 & 1.183 & 0.906 & 0.092 & 0.086 & 0.091 \\
\hline Manufactures & 6.325 & 12.524 & 6.378 & 0.31 & 0.363 & 0.309 & 0.315 & -0.367 & 0.231 & -0.179 & -0.193 & -0.177 \\
\hline Electronics & 7.028 & 13.347 & 7.789 & 0.07 & 0.072 & 0.063 & 0.027 & -1.09 & -0.516 & -0.09 & -0.099 & -0.09 \\
\hline Automobile & 8.15 & 14.769 & 8.279 & 0.816 & 0.897 & 0.814 & 0.36 & -0.772 & 0.232 & 0.078 & 0.11 & 0.082 \\
\hline Construct & 1.106 & 4.318 & 1.329 & 0.373 & 0.461 & 0.354 & -1.345 & -3.91 & -1.576 & -0.546 & -0.564 & -0.541 \\
\hline TradeServic & -0.706 & -1.027 & -0.747 & -0.008 & 0.004 & -0.008 & 0.247 & 0.411 & 0.246 & -0.012 & 0.025 & -0.011 \\
\hline TransComm & -0.027 & 0.244 & -0.014 & 0.094 & 0.129 & 0.092 & -0.131 & -0.375 & -0.167 & -0.017 & 0.027 & -0.015 \\
\hline FinanServ & -0.698 & -1.205 & -0.739 & -0.036 & -0.059 & -0.038 & 0.181 & 0.13 & 0.163 & 0.015 & 0.04 & 0.015 \\
\hline BusiServ & -0.43 & -0.411 & -0.433 & 0.004 & 0.08 & 0.003 & 0.007 & -0.255 & -0.029 & -0.025 & 0.004 & -0.025 \\
\hline PublicServ & -0.247 & 0.453 & -0.272 & -0.038 & 0.049 & -0.039 & 0.282 & 0.719 & 0.275 & 0.025 & 0.063 & 0.025 \\
\hline
\end{tabular}

Note: TFA: Trade Facilitation Agreement; TSE: Technological Spillover Effect.

${ }^{a}$ is calculated by total export percent (including FOB) change minus total output percent change

${ }^{b}$ is calculated by total import percent (including CIF) change minus private (household) consumption percent change

Source: GTAP 10A MRIO Data Base, author's estimation

\section{CONCLUSION REMARKS}

This paper analyzed the impact of an EPA between Africa and Japan through trade liberalization and reduction in NTBs. This study aimed to investigate sectoral interconnection participation in the EPA. Therefore, this paper made some policy recommendations regarding the regional and sectoral integration which could efficiently boost the GDP, welfare, and other opportunities of Japan-Africa businesses. We used the CGE model integrated with the GTAP-MRIO version 10A database. We first modified default closure to build the long-run closure and thereafter examined the AfJEPA with several possible EPA scenarios relying on the quantitative comparison of economic impacts of different technical measurements. As a result of this analysis, the AfJEPA would provide a new opportunity for Africa and Japan, as well as other regions. First, this agreement would contribute positive value to the existing African and Japanese MRTAs. Specifically, Namibia, Botswana, and Burkina Faso are the top three highest real GDP growth rate countries in Africa where electronics, petroleum and coal, and chemical, rubber, and plastic industries 
would comparatively have strong effects on their value-added. In addition to this, the EPA including Japan compared AfCFTA would boost remarkably real GDP in Egypt and Tunisia, and TSE-related electronics would have a relatively strong impact on Tunisia and the Rest of South Africa. Therefore, Africa would improve the production of the manufacturing sectors in total export. Likewise, the Japanese industries would improve their productivity in the motor vehicles and transport equipment, chemical, rubber, and plastic, and textiles and apparel industries. Briefly, we in line with previous studies suggested that (i) the AfJEPA would provide sustainable and promising growth strategy in African macro variables, (ii) trade facilitation and knowledge transfer, which policymakers can improve concrete action and investment, would considerably stimulate African real GDP and other macro variables, and (iii) only tariff liberalization policy would comparatively have less impact across regional real income growth. Thus, potential for growth would rely on how deep the integration policy would be.

To conclude, Japanese dependence on industrial input and output depending on import goods from African is between $1.1 \%$ to $5.5 \%$ throughout East Asian countries. Similarly, African output relying on Japanese products is $1.4 \%$. Therefore, the EPA would constitute a strategy for growth for Japan, which has been suffering from long-term economic stagnation, allowing Japan to integrate effects of growth outside of Asia. In addition to this, Africa would enhance its economic development strategy by learning from Japanese MRTAs' experiments and would have access to the Japanese high-tech market and capital.

Having said that, the limitation of this study is to face the difficulty of addressing ownership of capital shock correlated with welfare change and productivity shock-related real trade volume change; however, further study should consider a dynamic model for regional income on regional welfare and essentially examine the EPA integrated exporter and importer cost in NTBs. 


\section{REFERENCES}

Abrego, L., Amado, M. A., Gursoy, T., Nicholls, G. P., \& Perez-Saiz, H. (2019). The African continental free trade agreement: Welfare gains estimates from a general equilibrium model International Monetary Fund.

African Development Bank (AfDB). (2020). African development bank group: Annual report 2019. Côte d'Ivoire: AfDB. doi: SSN - 1737-8990 Retrieved from https://www.afdb.org/en/documents/annualreport-2019

Aguiar, A., Chepeliev, M., Corong, E. L., McDougall, R., \& van der Mensbrugghe, D. (2019). The GTAP database: Version 10. Journal of Global Economic Analysis, 4(1), 1-27.

Aldaba, R. M. (2012). No title. Trade Reforms, Competition, and Innovation in the Philippines,

Asian Development Bank (ADB) and the United Nations Economic and Social Commission for Asia and the Pacific (ESCAP). (2013). Designing and implementing trade facilitation in Asia and the Pacific (The third Edition ed.). Mandaluyong: ADB and UNESCAP. doi:SBN 978-92-9254-200-9

Biyik, O. (2020). Winner and loser in terms of the FTAs and the trade war: A case study of the Japanese market. examination of the GTAP10 database.

Carrico, C., Corong, E., \& van der Mensbrugghe, D. (2020). No title. The GTAP Version 10A Multi-Region Input-Output (MRIO) Data Base,

Coe, D., Helpman, E., \& Hoffmaister, A. (1997). North-south R\&D spillovers. The Economic Journal, 107(440), 134-149.

Dixon, P., Parmenter, B., \& Rimmer, R. (1981). No title. Extending the ORANI Model of the Australian Economy: Adding Foreign Investment to a Miniature Version,

Felbermayr, G., Kimura, F., Okubo, T., \& Steininger, M. (2019). Quantifying the EU-japan economic partnership agreement. Journal of the Japanese and International Economies, 51, 110-128.

Francois, J. F., Nordstrom, H., \& McDonald, B. (1996). No title. Liberalization and Capital Accumulation in the GTAP Model,

Freund, C., Ferrantino, M., Maliszewska, M., \& Ruta, M. (2018). Impacts on global trade and income of current trade disputes. Macroeconomics, Trade Investment (MTI) Practice Notes, July, 2

Grübler, J., Reiter, O., \& Stehrer, R. (2019). The EU-japan EPA: A case for non-tariff Measures1. Paper presented at the CESifo Forum, , 20(2) 17-25.

Herghelegiu, C. (2018). The political economy of non-tariff measures. The World Economy, 41(1), 262286.

Hertel, T. W. (1997). Global trade analysis: Modeling and applications Cambridge university press. 
Hertel, T. (2013). Global applied general equilibrium analysis using the global trade analysis project framework doi:10.1016/B978-0-444-59568-3.00012-2

Hertel, T. W., Walmsley, T., \& Itakura, K. (2001). Dynamic effects of the" new age" free trade agreement between Japan and Singapore. Journal of Economic Integration, 446-484.

Hillberry, R., \& Zhang, X. (2018). Policy and performance in customs: Evaluating the trade facilitation agreement. Review of International Economics, 26(2), 438-480.

Jafari, Y., \& Tarr, D. G. (2017). Estimates of ad valorem equivalents of barriers against foreign suppliers of services in eleven services sectors and 103 countries. World Economy, 40(3), 544-573. doi:10.1111/twec.12329

Ji, X., Rana, P., Chia, W., \& Li, C. (2018). Post-TPP trade policy options for ASEAN and its dialogue partners:'Preference ordering using CGE analysis. East Asian Economic Review, 22(2), 177-215.

Kawasaki, K. (2015). The relative significance of EPAs in Asia-Pacific. Journal of Asian Economics, 39, 19-30.

Kawasaki, K. (2017). Emergent uncertainty in regional integration-economic impacts of alternative RTA scenarios.

Kawasaki, K., Narayanan, B. G., Guimbard, H., \& Kuno, A. (2019). Analysis of the role of tariff concessions in east Asia. Margin: The Journal of Applied Economic Research, 13(2), 141-167.

Kee, H., Nicita, A., \& Olarreaga, M. (2009). Estimating trade restrictiveness indices. The Economic Journal, 119(534), 172-199.

Kuwayama, M. (2019). No title. TPP11 (CPTPP): Its Implications for Japan-Latin America Trade Relations in Times of Uncertainty,

Malcolm, G. (1998). Modeling country risk and capital flows in GTAP.

Maliszewska, M., \& Ruta, M. (2020). The African continental free trade area: Economic and distributional effects. World Bank, Washington, DC,

Nabeshima, K., Kashcheeva, M., \& Kang, B. (2018). The impacts of export competition on international technology flows. Applied Economics Letters, 25(15), 1058-1061.

Owen, A. (2017). Techniques for evaluating the differences in multiregional input-output databases. Cham: Springer International Publishing.

Petri, P. A., \& Plummer, M. G. (2016). The economic effects of the trans-pacific partnership: New estimates. Peterson Institute for International Economics Working Paper, (16-2)

Rahman, M. M., \& Ara, L. A. (2015). TPP, TTIP, and RCEP: Implications for South Asian economies. South Asia Economic Journal, 16(1), 27-45. doi:10.1177/1391561415575126

Timmer, C. P. (1988). The agricultural transformation. Handbook of Development Economics, 1, 275-331. 
Urata, S. (2016). Mega-FTAs and the WTO: Competing or complementary? International Economic Journal, 30(2), 231-242.

Urata, S. (2019). US-Japan trade frictions: The past, the present, and implications for the US-China trade war. Asian Economic Policy Review,

van Meijl, H., \& van Tongeren, F. (1999). Endogenous international technology spillovers and biased technical change in agriculture. Economic Systems Research, 11(1), 31-48.

Walmsley, T. L. (1998). Long run simulations with GTAP: Illustrative results from APEC trade liberalization.

Walmsley, T. L., Hertel, T., \& Hummels, D. (2014). Developing a GTAP-based multi-region, input-output framework for supply chain analysis. Asia and global production networks () Edward Elgar Publishing, $16-80$.

Walmsley, T., \& Strutt, A. (2019). Improving the modeling of non-tariff measures in a CGE framework.

Webb, M., Strutt, A., Gibson, J., \& Walmsley, T. (2020). Modeling the impact of non-tariff measures on supply chains in ASEAN. World Economy, 43(8), 2172-2198. doi:10.1111/twec.12955

World Bank. (2020a). The African continental free trade area: Economic and distributional effects. doi:10.1596/978-1-4648-1559-1

World Bank. (2020b). World development report 2020: Trading for development in the age of global value chains Washington, DC: World Bank. doi:10.1596/978-1-4648-1457-0

World Trade Organization. (2019). World trade report 2019: The future of services trade. (). WTO Publications: World Trade Organization. Retrieved from https://www.wto.org/english/res e/publications e/publications e.htm 


\section{APPENDIX}

\section{Appendix I: Modification to the Standard GTAP Model for the Long-Run Closure}

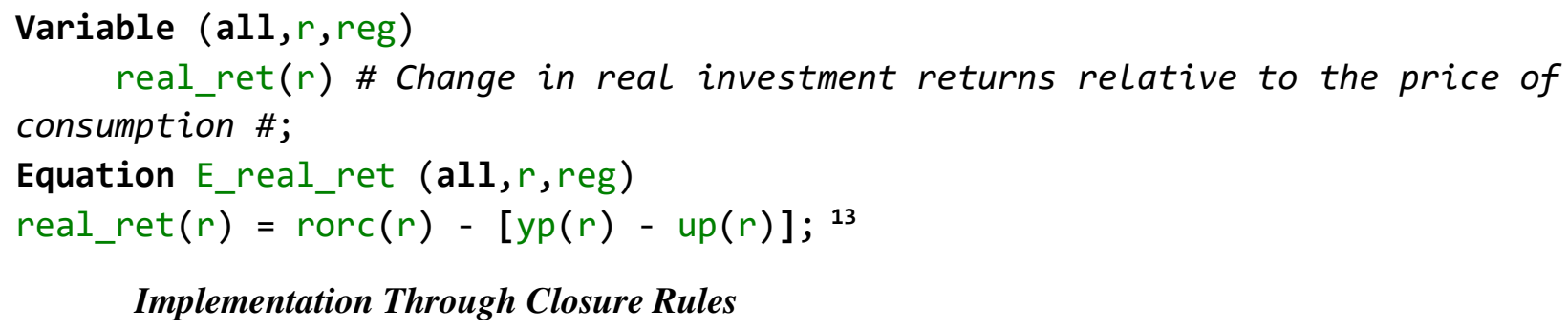

This paper created subset variables for the steady-state such as REGLESS1 which equals All regions - Rest of World (ROW). In this example, the ROW region will act as the lender/borrow of last resort ${ }^{14}$.

Technically, the availability of capital within a country is not active, instead global saving should be able to finance global investment. Therefore, we used two different closures to examine the long-run effects. Particularly, the "expand(e,r)", which is the highly welfare gain-related variable, is the change in investment relative to endowment stock. The " $\operatorname{rorc}(r)$ ", which is the highly GDP growth-focused variable, is the current net rate of return on capital stock in the region (r). These two different closures with capital mobility under a steady-state developed by Francois et al. (1996) and Walmsley (1998). In that case this paper assumed the current rate of return (rorc[r]) is equal to expected rate of return (rore[r]) by RORDELTA value $=0$ (Dixon, Parmenter, $\&$ Rimmer, 1981). The following variables are exogenous/endogenous:

qe("capital",REGLESS1) endogenous

cgdslack(REGLESS1) exogenous

expand("capital",REGLESS1) exogenous

real_ret(REGLESS1) endogenous

Moreover, the second approach is (perfect) capital mobility. This paper assumes RORDELTA value $=0$. The following variables are exogenous/endogenous

qe("capital",REGLESS1) endogenous

cgdslack(REGLESS1) exogenous

rorc(REGLESS1) exogenous

real_ret(REGLESS1) endogenous

\footnotetext{
${ }^{13}$ Change in real return to investment that is calculated as the difference between the price of the current composite consumption good relative to the real return to the capital good

${ }^{14}$ However, it can be any region - e.g., EU, USA.
} 


\section{Appendix II: Descriptive Statistics}

\section{Table A1: Regional Aggregation}

\begin{tabular}{|c|c|c|}
\hline \multicolumn{2}{|l|}{ Region } & GTAP concordance \\
\hline \multicolumn{2}{|l|}{ Japan (JPN) } & Japan (JPN) \\
\hline \multicolumn{2}{|l|}{ Korea (KOR) } & Republic of Korea (KOR) \\
\hline \multicolumn{2}{|l|}{ China (CHN) } & China (CHN) \\
\hline \multicolumn{2}{|c|}{ United States (USA) } & United States of America (USA) \\
\hline \multicolumn{2}{|l|}{ India (IND) } & India (IND) \\
\hline \multicolumn{2}{|l|}{ ANZ } & Australia (AUS), New Zealand (NZL) \\
\hline \multicolumn{2}{|l|}{ ASEAN6 } & $\begin{array}{l}\text { Cambodia (KHM), Indonesia (IDN), Lao PDR (LAO), Philippines (PHL), Thailand (THA), rest of } \\
\text { Southeast Asia-Myanmar-(XSE) }\end{array}$ \\
\hline \multicolumn{2}{|l|}{ ASEAN4 } & Malaysia (MYS), Singapore (SGP), Brunei Darussalam (BRN), Vietnam (VNM) \\
\hline \multicolumn{2}{|l|}{ CMCP } & Canada (CAN), Mexico (MEX), Chile (CHL), Peru (PER) \\
\hline \multicolumn{2}{|c|}{ The European Union (EU) } & $\begin{array}{l}\text { Austria (AUT), Belgium (BEL), Cyprus (CYP), Czech Republic (CZE), Denmark (DNK), Estonia } \\
\text { (EST), Finland (FIN), France (FRA), Germany (DEU), Greece (GRC), Hungary (HUN), Ireland (IRL), } \\
\text { Italy (ITA), Latvia (LVA), Lithuania (LTU), Luxembourg (LUX), Malta (MLT), Netherlands (NLD), } \\
\text { Poland (POL), Portugal (PRT), Slovakia (SVK), Slovenia (SVN), Spain (ESP), Sweden (SWE), } \\
\text { Bulgaria (BGR), Croatia (HRV), Romania (ROU) }\end{array}$ \\
\hline \multirow{5}{*}{$\begin{array}{l}\text { African } \\
\text { Continental } \\
\text { Free Trade } \\
\text { Area } \\
\text { (AfCFTA) } \\
\text { Countries }\end{array}$} & Northern Africa & Egypt, Arab Rep. (EGY), Morocco (MAR), Tunisia (TUN), Rest of North Africa (XNF), \\
\hline & Central African & Cameroon (CMR), Central Africa (XCF), Congo, Dem. Rep. (COD=XAC), \\
\hline & Southern Africa & Botswana (BWA), Namibia (NAM), South Africa (ZAF), Rest of South African Customs Union (XSC) \\
\hline & East African & $\begin{array}{l}\text { Ethiopia (ETH), Kenya (KEN), Madagascar (MDG), Malawi (MWI), Mauritius (MUS), Mozambique } \\
\text { (MOZ), Rwanda (RWA), Tanzania (TZA), Uganda (UGA), Zambia (ZMB), Zimbabwe (ZWE), Rest of } \\
\text { East Africa (XEC), }\end{array}$ \\
\hline & Western Africa & $\begin{array}{l}\text { Burkina Faso (BFA), Côte d'Ivoire (CIV), Ghana (GHA), Benin (BEN), Guinea (GIN), Nigeria (NGA), } \\
\text { Senegal (SEN), Togo (TGO), Rest of West Africa (XWF), }\end{array}$ \\
\hline Rest of Worl & (ROW) & $\begin{array}{l}\text { Hong Kong, SAR, China (HKG), Mongolia (MNG), Taiwan, China (TWN), rest of East Asia (XEA), } \\
\text { United Kingdom (GBR), Switzerland (CHE), Norway (NOR), rest of EFTA (XEF), rest of Oceania } \\
\text { (XOC), Bangladesh (BGD), Nepal (NPL), Pakistan (PAK), Sri Lanka (LKA), rest of South Asia (XSA), } \\
\text { rest of North America (XNA), Argentina (ARG), Bolivia (BOL), Brazil (BRA), Colombia (COL), } \\
\text { Ecuador (ECU), Paraguay (PRY), Uruguay (URY), Venezuela (VEN), rest of South America (XSM), } \\
\text { Costa Rica (CRI), Guatemala (GTM), Honduras (HND), Nicaragua (NIC), Panama (PAN), El Salvador } \\
\text { (SLV), rest of Central America (XCA), Dominican Republic (DOM), Jamaica (JAM), Puerto Rico } \\
\text { (PRI), Trinidad and Tobago (TTO), rest of Caribbean (XCB), Albania (ALB), Belarus (BLR), Russian } \\
\text { Federation (RUS), Ukraine (UKR), rest of East Europe (XEE), rest of Europe (XER), Kazakhstan } \\
\text { (KAZ), Kyrgyzstan (KGZ), Tajikistan (TJK), rest of former Soviet Union (XSU), Armenia (ARM), } \\
\text { Azerbaijan (AZE), Georgia (GEO), Bahrain (BHR), Iran, Islamic Rep. (IRN), Israel (ISR), Jordan } \\
\text { (JOR), Kuwait (KWT), Oman (OMN), Qatar (QAT), Saudi Arabia (SAU), Turkey (TUR), United Arab } \\
\text { Emirates (ARE), rest of Western Asia (XWS), rest of the world (XTW) }\end{array}$ \\
\hline
\end{tabular}

Note: ${ }^{a}$ See https://www.gtap.agecon.purdue.edu/databases/regions.aspx?version=10.131 for the GTAP countries and regions.

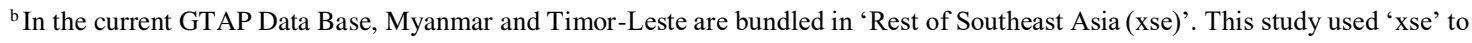

represent Myanmar. Likewise, South centrical Africa (XAC) represents Congo.

Source: Source: author's aggregation based on GTAP 10A MRIO Data Base. 


\section{Table A2: Sectoral Aggregation}

\begin{tabular}{|c|c|}
\hline Sector name & GTAP concordance \\
\hline Agriculture (AGR) & $\begin{array}{l}\text { Paddy rice (PDR); wheat (WHT); cereal grains, NEC (GRO); vegetables, fruit, nuts } \\
\text { (V_F); oilseeds (OSD); sugar cane, sugar beet (C_B); plant-based fibers (PFB); crops, } \\
\text { NEC (OCR); bovine cattle, sheep and goats, horses (CTL); animal products, NEC } \\
\text { (OAP); raw milk (RMK); wool, silkworm cocoons (WOL); forestry (FRS) }\end{array}$ \\
\hline Fossil fuels (FFL) & Coal (COA); oil (OIL); gas (GAS), gas manufacture, distribution (GDT) \\
\hline Minerals, NES (OXT) & Other extraction (formerly other manufacturing (omn) minerals, NEC) (OXT) \\
\hline Processed foods (PFD) & $\begin{array}{l}\text { Fish (FSH); bovine meat products (CMT); meat products, NEC (OMT); vegetable oils } \\
\text { and fats (VOL); dairy products (MIL); processed rice (PCR); sugar (SGR); food } \\
\text { products, NEC (OFD); beverages and tobacco products (B_T) }\end{array}$ \\
\hline Wood and paper products (WPP) & Wood products (LUM); paper products, publishing (PPP) \\
\hline Textiles and wearing apparel (TWP) & Textiles (TEX); wearing apparel (WAP); leather products (LEA) \\
\hline Energy-intensive manufacturing (KE5) & Mineral products, NEC (NMM); ferrous metals (I_S); metals, NEC (NFM) \\
\hline Petroleum and coal products $\left(\mathbf{P}_{-} \mathbf{C}\right)$ & Petroleum, coal products (P_C) \\
\hline Chemical, rubber, and plastic products (CRP) & $\begin{array}{l}\text { Chemical products (CHM); basic pharmaceutical products (BPH); rubber and plastic } \\
\text { products (RPP) }\end{array}$ \\
\hline Manufactures, NES (XMN) & Metal products (FMP); manufactures, NEC (OMF) \\
\hline Electronics (XELE) & Computer, electronic, and optical products (ELE); electrical equipment (EEQ); \\
\hline Motor vehicles and Machinery (XMVH) & $\begin{array}{l}\text { Motor vehicles and parts (MVH); transport equipment nec (OTN); machinery and } \\
\text { equipment nec (OMG) }\end{array}$ \\
\hline Construction (CNS) & Construction (CNS) \\
\hline Trade services (TRD) & $\begin{array}{l}\text { Trade (TRD); accommodation, food, and service activities (AFS); warehousing and } \\
\text { support activities (WHS) }\end{array}$ \\
\hline Transport and Communication Service (TPCS) & $\begin{array}{l}\text { Transport, NEC (OTP); communication (CMN); water transport (WTP); air transport } \\
\text { (ATP); }\end{array}$ \\
\hline Financial services, NEC (OFI) & Financial services, NEC $(\mathrm{OFI})$ \\
\hline Business services (XBS) & $\begin{array}{l}\text { Real estate activities (RSA); business services, NEC (OBS); insurance (formerly ISR) } \\
\text { (INS) }\end{array}$ \\
\hline Public services (XSV) & $\begin{array}{l}\text { Electricity (ELY); water (WTR); recreational and other service (ROS); public } \\
\text { administration and defense (OSG); education (EDU); human health and social work } \\
\text { activities (HHT); dwellings (DWE) }\end{array}$ \\
\hline
\end{tabular}

Table A3: Structure of Each Region

\begin{tabular}{|c|c|c|c|c|c|c|c|c|}
\hline \multirow{2}{*}{ Region } & \multicolumn{5}{|c|}{ Percent of Expenditure in GDP } & \multirow{2}{*}{$\begin{array}{c}\text { GDP value } \\
\text { (US\$ millions) }\end{array}$} & \multirow{2}{*}{$\begin{array}{c}\text { (\%) GDP in } \\
\text { the World }\end{array}$} & \multirow{2}{*}{$\begin{array}{c}\text { (\%) Population } \\
\text { in the World }\end{array}$} \\
\hline & Cons & Inv & Gov & $\operatorname{Exp}$ & Imp & & & \\
\hline Japan & $59 \%$ & $21 \%$ & $20 \%$ & $20 \%$ & $-20 \%$ & $\$ 4,596,162$ & $6 \%$ & $1.8 \%$ \\
\hline Korea & $51 \%$ & $29 \%$ & $15 \%$ & $48 \%$ & $-44 \%$ & $\$ 1,411,312$ & $2 \%$ & $0.7 \%$ \\
\hline China & $38 \%$ & $44 \%$ & $14 \%$ & $24 \%$ & $-20 \%$ & $\$ 10,351,105$ & $13 \%$ & $18.8 \%$ \\
\hline USA & $69 \%$ & $20 \%$ & $15 \%$ & $11 \%$ & $-15 \%$ & $\$ 17,348,106$ & $22 \%$ & $4.4 \%$ \\
\hline India & $60 \%$ & $32 \%$ & $11 \%$ & $21 \%$ & $-25 \%$ & $\$ 2,042,442$ & $3 \%$ & $17.9 \%$ \\
\hline$A N Z$ & $55 \%$ & $26 \%$ & $18 \%$ & $21 \%$ & $-19 \%$ & $\$ 1,654,988$ & $2 \%$ & $0.4 \%$ \\
\hline ASEAN6 & $60 \%$ & $29 \%$ & $12 \%$ & $37 \%$ & $-38 \%$ & $\$ 1,675,916$ & $2 \%$ & $6.9 \%$ \\
\hline ASEAN4 & $55 \%$ & $29 \%$ & $12 \%$ & $94 \%$ & $-90 \%$ & $\$ 847,758$ & $1 \%$ & $1.8 \%$ \\
\hline CMCP & $62 \%$ & $23 \%$ & $17 \%$ & $30 \%$ & $-32 \%$ & $\$ 3,543,215$ & $5 \%$ & $2.9 \%$ \\
\hline $\boldsymbol{E} \boldsymbol{U}$ & $57 \%$ & $20 \%$ & $22 \%$ & $41 \%$ & $-40 \%$ & $\$ 15,542,450$ & $20 \%$ & $6.1 \%$ \\
\hline Africa/AfCFTA & $66 \%$ & $22 \%$ & $15 \%$ & $28 \%$ & $-31 \%$ & $\$ 2,812,808$ & $4 \%$ & $17 . \%$ \\
\hline ROW & $59 \%$ & $22 \%$ & $18 \%$ & $29 \%$ & $-28 \%$ & $\$ 16,399,854$ & $21 \%$ & $21.4 \%$ \\
\hline AJCEPA & $59 \%$ & $24 \%$ & $17 \%$ & $33 \%$ & $-33 \%$ & $\$ 7,119,836$ & $9 \%$ & $10.4 \%$ \\
\hline CPTPP & $59 \%$ & $23 \%$ & $18 \%$ & $29 \%$ & $-30 \%$ & $\$ 10,642,123$ & $14 \%$ & $6.8 \%$ \\
\hline RCEP & $47 \%$ & $35 \%$ & $15 \%$ & $29 \%$ & $-26 \%$ & $\$ 20,537,241$ & $26 \%$ & $30.3 \%$ \\
\hline EUJEPA & $57 \%$ & $21 \%$ & $21 \%$ & $36 \%$ & $-36 \%$ & $\$ 20,138,612$ & $26 \%$ & $7.9 \%$ \\
\hline AfJEPA & $62 \%$ & $22 \%$ & $18 \%$ & $23 \%$ & $-24 \%$ & $\$ 7,408,970$ & $9 \%$ & $18.8 \%$ \\
\hline
\end{tabular}

Note 1: Cons: Consumption; Inv: investment; Gov: Government expenditure; Exp: Export; Imp: Import.

Note 2: ANZ: Australia and New Zealand; ASEAN4: Singapore, Malaysia, Vietnam, and Brunei; ASEAN6: Cambodia, Indonesia, Lao PDR,

Malaysia, Myanmar, and the Philippines; CMCP: Canada, Mexico, Chile, and Peru.

Source: GTAP 10A MRIO Data Base, author's calculations. 
Table A4: Percent of Japanese and African Total Trade

\begin{tabular}{lcc|cc}
\hline & \multicolumn{2}{c|}{ Japan } & \multicolumn{2}{c}{ Africa } \\
\cline { 2 - 5 } Japan & Export & Import & Export & Import \\
\hline Korea & - & - & $\mathbf{2 . 7 \%}$ & $\mathbf{2 . 0 \%}$ \\
\hline China & $6.6 \%$ & $4.1 \%$ & $2.7 \%$ & $2.4 \%$ \\
\hline USA & $\mathbf{2 6 . 0 \%}$ & $\mathbf{2 1 . 9 \%}$ & $\mathbf{1 3 . 4 \%}$ & $\mathbf{1 5 . 4 \%}$ \\
\hline India & $15.6 \%$ & $9.8 \%$ & $8.3 \%$ & $7.4 \%$ \\
\hline ANZ & $1.2 \%$ & $1.2 \%$ & $8.3 \%$ & $4.9 \%$ \\
\hline ASEAN6 & $2.4 \%$ & $5.7 \%$ & $0.7 \%$ & $0.9 \%$ \\
\hline ASEAN4 & $5.6 \%$ & $7.1 \%$ & $1.8 \%$ & $2.4 \%$ \\
\hline CMCP & $4.3 \%$ & $3.4 \%$ & $1.6 \%$ & $2.1 \%$ \\
\hline EU & $\mathbf{1 1 . 0 \%}$ & $\mathbf{1 1 . 6 \%}$ & $\mathbf{2 9 . 1 \%}$ & $\mathbf{2 8 . 4 \%}$ \\
\hline Africa & $\mathbf{2 . 0 \%}$ & $\mathbf{2 . 3 \%}$ & $11.6 \%$ & $10.8 \%$ \\
\hline ROW & $17.7 \%$ & $26.9 \%$ & $18.3 \%$ & $22.0 \%$ \\
\hline SOUrC: GTAP $10 A$ &
\end{tabular}

Source: GTAP 10A MRIO Data Base, author's calculations.

Table A5: Ad Valorem Rate Import Taxes, by Source

\begin{tabular}{lccccccccc}
\hline$\%$ & Japan & Korea & China & ANZ & ASEAN6 & ASEAN4 & CMCP & EU & Africa \\
\hline Japan & 0 & 67 & 68 & 35 & 34 & 23 & 11 & 31 & 70 \\
\hline Korea & 31 & 0 & 71 & 41 & 22 & 55 & 24 & 3 & 85 \\
\hline China & 25 & 175 & 0 & 27 & 16 & 24 & 33 & 40 & 135 \\
\hline ANZ & 60 & 98 & 39 & 0 & 31 & 11 & 13 & 46 & 62 \\
\hline ASEAN6 & 16 & 55 & 7 & 2 & 12 & 8 & 35 & 22 & 108 \\
\hline ASEAN4 & 11 & 60 & 8 & 2 & 9 & 10 & 39 & 24 & 102 \\
\hline CMCP & 41 & 59 & 47 & 17 & 58 & 20 & 2 & 13 & 87 \\
\hline EU & 44 & 66 & 69 & 31 & 69 & 40 & 13 & 0 & 59 \\
\hline Africa & 17 & 198 & 48 & 36 & 54 & 33 & 26 & 4 & 43 \\
\hline
\end{tabular}

Note1: Rows represent exporters; columns represent importers.

Source: GTAP 10A Data Base, author's calculations.

Table A: Japanese Productive Sector by Each FTA

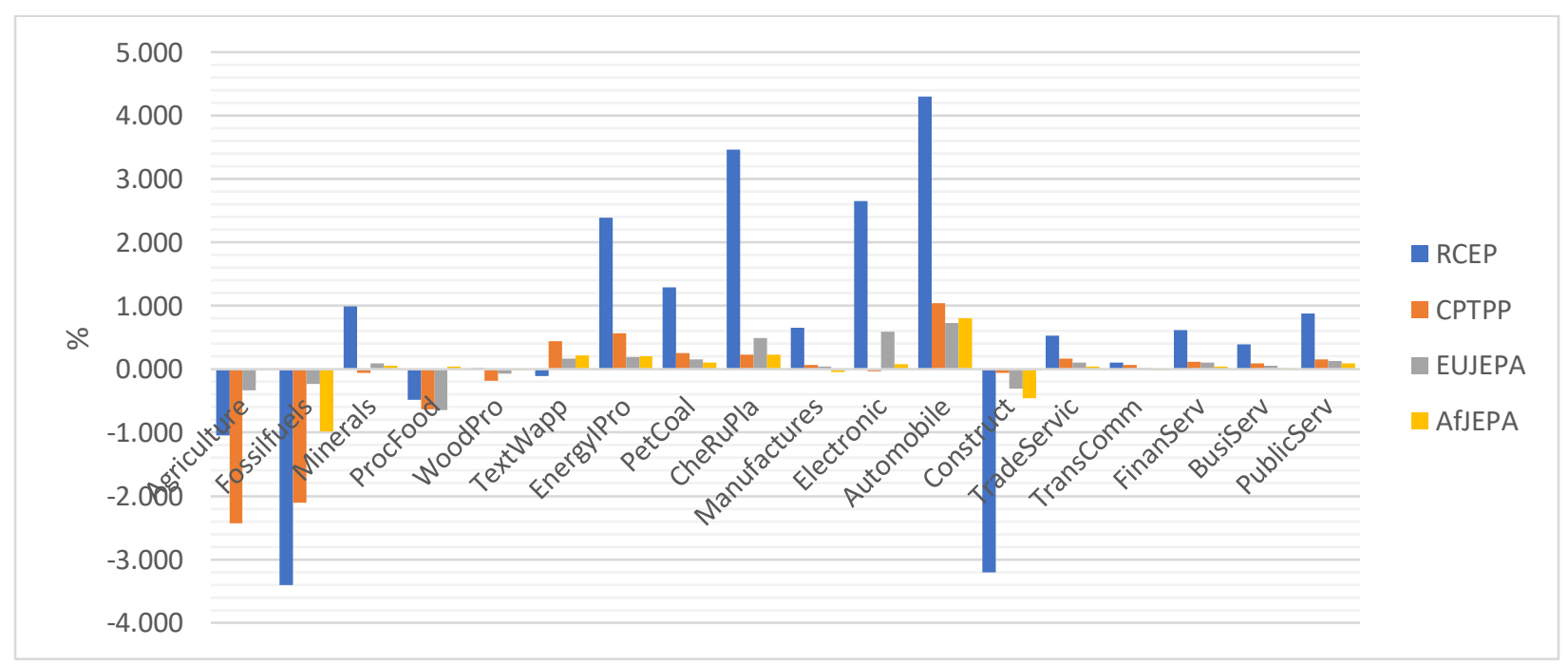

Source: GTAP 10A MRIO Data Base, author's estimation 


\section{Appendix III: Result of MRTAs with Different Approaches}

\section{Japan and Africa Integration Under Standard GTAP Model}

We investigated Japan and African integration by examining the MRTAs (Table 3) under special conditions. The special approach of GTAP, in which we modified closure and parameters' values to be 0 or 1 , is to interpret integration between countries as close as World Input-Output Database (WIOD) does. That is, this approach allows scholars to track international trade-based sectoral integration. Accordingly, another question in the paper was to determine the production cycle and the form of international fragmentation of production that represents sectoral integration between Japan and Africa as an example. Thus, Table A6 shows that Japanese industries integrated into Africa through East Asia has a large impact than ASEAN countries. In other words, when Japanese industrial output increases by $0.274 \%$ through RCEP which would trigger African industry to increase by $0.015 \%$. Similarly, African output, increasing by $0.276 \%$, is in need to meet Japanese industrial output, enhancing by $0.004 \%$, when the AfCFTA concluded. Indeed, Japanese output relying on African export products is between 1.1\% to 5.5\% through MRTAs and African industrial output interacting with Japanese export goods depends on $1.4 \%$ by AfCFTA. It seems that the sectoral interconnection between Japan and Africa could have a strong effect on their macro variables through East Asia countries and India (Table A6). In this sense, the purpose of this paper was to investigate how these countries boost their GDP growth and other opportunities if there is a possible EPA (AfJEPA) that would create opportunities for the Japan-African businesses.

Table A6: Japan and African Integration Through MRTAs

\begin{tabular}{|c|c|c|c|c|c|}
\hline & \multicolumn{5}{|c|}{ Standard Model (RORDELTA=1) } \\
\hline & АЈСEPA & CPTPP & RCEP & EUJEPA & AfCFTA \\
\hline Japan & 0.081 & 0.092 & 0.274 & 0.066 & 0.004 \\
\hline Africa & 0.003 & 0.001 & 0.015 & 0.001 & 0.276 \\
\hline Korea & 0.007 & 0.011 & 0.633 & 0.005 & 0.008 \\
\hline China & 0.007 & 0.01 & 0.22 & 0.013 & 0.009 \\
\hline USA & 0.001 & 0.001 & 0.006 & 0.001 & 0.001 \\
\hline India & 0.004 & 0.004 & 0.012 & 0.002 & 0.014 \\
\hline$\overline{\mathbf{A Z}}$ & 0.007 & 0.107 & 0.263 & 0.007 & 0.002 \\
\hline ASEAN6 & 0.295 & 0.003 & 0.553 & 0.004 & 0.003 \\
\hline ASEAN4 & 0.462 & 0.371 & 1.067 & 0.003 & 0.002 \\
\hline СМСР & 0.003 & 0.083 & 0.016 & 0.002 & 0 \\
\hline EU & 0.003 & 0.002 & 0.017 & 0.039 & 0.008 \\
\hline
\end{tabular}

Note 1: ANZ: Australia and New Zealand; ASEAN4: Singapore, Malaysia, Vietnam, and Brunei; ASEAN6: Cambodia, Indonesia, Lao PDR,

Malaysia, Myanmar, and the Philippines; CMCP: Canada, Mexico, Chile, and Peru.

Source: GTAP 10A MRIO Data Base, author's calculations.

\section{AfCFTA and AfJEPA-E Contribution to Africa}

Table A7 shows each African country's real GDP growth by the AfCFTA and AfJEPA-E in which we presented the contribution of the Japanese market to the individual African country. Therefore, each country would enhance their real GDP due to the AfJEPA-E, boosting between $0.74 \%$ and $10.14 \%$ (Table A7). Including Japan in the EPA compared to the AfCFTA would remarkably hike up real GDP in Egypt and Tunisia, increasing from $0.07 \%$ to $0.30 \%$ and from $0.17 \%$ to $0.43 \%$, respectively. This paper, such as WB (2020a) and Abrego (2019), reported that facilitation improvement compared to tariffs elimination would stimulate significantly individual economies in Africa. On the one hand, TSE-related electronics would 
have a strong impact on Tunisia and the Rest of South Africa and would have less effect on the Rest of West Africa and Côte d'Ivoire. Moreover, the individual country would comparatively be sensitive (to) from TFA. For instance, TFA's impact on Zambia, Madagascar, and Botswana would boost particularly their real GDP about eight times higher than TSE. To put it briefly, the opening of a deal or a country reaching larger / more markets, the more economically stimulating the country's GDP growth.

\section{Table A7: Contribution to Each African Country's Real GDP}

\begin{tabular}{|c|c|c|c|c|c|}
\hline & \multirow{2}{*}{ AfCFTA } & \multicolumn{4}{|c|}{ AfJEPA-E } \\
\hline & & Total & Tariffs only & Tariffs and TFA & Tariffs and TSE \\
\hline Egypt & 0.066 & 0.302 & 0.179 & 0.261 & 0.221 \\
\hline Morocco & 0.186 & 0.273 & 0.061 & 0.23 & 0.104 \\
\hline Tunisia & 0.168 & 0.426 & 0.018 & 0.333 & 0.111 \\
\hline Rest of North Africa & 0.473 & 0.641 & 0.256 & 0.584 & 0.313 \\
\hline Burkina Faso & 3.969 & 4.044 & 2.242 & 3.999 & 2.287 \\
\hline Cameroon & 0.544 & 0.603 & 0.398 & 0.59 & 0.411 \\
\hline Côte d'Ivoire & 0.629 & 0.681 & 0.19 & 0.67 & 0.2 \\
\hline Ghana & 1.363 & 1.406 & 0.822 & 1.386 & 0.843 \\
\hline Rest of West Africa & 2.438 & 3.213 & 2.042 & 3.191 & 2.063 \\
\hline Nigeria & 0.413 & 0.563 & 0.278 & 0.527 & 0.314 \\
\hline Senegal & 1.674 & 1.817 & 0.689 & 1.738 & 0.768 \\
\hline Central Africa & 1.687 & 1.84 & 0.997 & 1.796 & 1.041 \\
\hline Ethiopia & 0.217 & 0.314 & 0.241 & 0.303 & 0.251 \\
\hline Kenya & 0.496 & 0.769 & 0.353 & 0.715 & 0.407 \\
\hline Madagascar & 0.275 & 0.425 & 0.088 & 0.394 & 0.12 \\
\hline Malawi & 1.976 & 2.206 & 0.962 & 2.178 & 0.99 \\
\hline Mauritius & 0.62 & 0.741 & 0.158 & 0.696 & 0.203 \\
\hline Mozambique & 2.95 & 3.118 & 0.754 & 3.095 & 0.777 \\
\hline Rwanda & 0.782 & 0.862 & 0.278 & 0.854 & 0.286 \\
\hline Tanzania & 0.787 & 0.875 & 0.561 & 0.863 & 0.573 \\
\hline Uganda & 1.191 & 1.628 & 0.947 & 1.544 & 1.031 \\
\hline Zambia & 0.989 & 1.072 & 0.067 & 1.051 & 0.087 \\
\hline Zimbabwe & 3.624 & 3.833 & 1.478 & 3.756 & 1.556 \\
\hline Rest of East Africa & 0.382 & 0.475 & 0.181 & 0.446 & 0.21 \\
\hline Botswana & 4.748 & 4.938 & 0.602 & 4.91 & 0.63 \\
\hline Namibia & 9.875 & 10.139 & 2.692 & 10.042 & 2.79 \\
\hline South Africa & 0.453 & 0.89 & 0.357 & 0.801 & 0.447 \\
\hline Rest of South Africa & 0.545 & 0.764 & 0.069 & 0.582 & 0.252 \\
\hline
\end{tabular}

Note: TFA: Trade Facilitation Agreement; TSE: Technological Spillover Effect.

Source: GTAP 10A MRIO Data Base, author's calculations. 